\title{
Controls on fault zone structure and brittle fracturing in the foliated hanging wall of the Alpine Fault
}

\author{
Jack N. Williams ${ }^{1, a}$, Virginia G. Toy ${ }^{1}$, Cécile Massiot ${ }^{2,3}$, David D. McNamara ${ }^{3,4}$, Steven A. F. Smith ${ }^{1}$, and Steven Mills ${ }^{5}$ \\ ${ }^{1}$ Department of Geology, University of Otago, P.O. Box 56, Dunedin 9054, New Zealand \\ ${ }^{2}$ School of Geography, Environment, and Earth Sciences, Victoria University of Wellington, \\ P.O. Box 600, Wellington 6012, New Zealand \\ ${ }^{3}$ GNS Science, P.O. Box 30-368, Lower Hutt 5040, New Zealand \\ ${ }^{4}$ Department of Earth and Ocean Sciences, NUI Galway, University Road, Galway, Ireland \\ ${ }^{5}$ Department of Computer Science, University of Otago, P.O. Box 56, Dunedin 9054, New Zealand \\ anow at: School of Earth and Ocean Sciences, Cardiff University, Cardiff, CF10 3AT, UK
}

Correspondence: Jack Williams (williamsj132@cardiff.ac.uk)

Received: 4 October 2017 - Discussion started: 10 October 2017

Revised: 18 March 2018 - Accepted: 19 March 2018 - Published: 23 April 2018

\begin{abstract}
Three datasets are used to quantify fracture density, orientation, and fill in the foliated hanging wall of the Alpine Fault: (1) X-ray computed tomography (CT) images of drill core collected within $25 \mathrm{~m}$ of its principal slip zones (PSZs) during the first phase of the Deep Fault Drilling Project that were reoriented with respect to borehole televiewer images, (2) field measurements from creek sections up to $500 \mathrm{~m}$ from the PSZs, and (3) CT images of oriented drill core collected during the Amethyst Hydro Project at distances of $\sim 0.7-2 \mathrm{~km}$ from the PSZs. Results show that within $160 \mathrm{~m}$ of the PSZs in foliated cataclasites and ultramylonites, gouge-filled fractures exhibit a wide range of orientations. At these distances, fractures are interpreted to have formed at relatively high confining pressures and/or in rocks that had a weak mechanical anisotropy. Conversely, at distances greater than $160 \mathrm{~m}$ from the PSZs, fractures are typically open and subparallel to the mylonitic or schistose foliation, implying that fracturing occurred at low confining pressures and/or in rocks that were mechanically anisotropic. Fracture density is similar across the $\sim 500 \mathrm{~m}$ width of the field transects. By combining our datasets with measurements of permeability and seismic velocity around the Alpine Fault, we further develop the hierarchical model for hangingwall damage structure that was proposed by Townend et al. (2017). The wider zone of foliation-parallel fractures represents an "outer damage zone" that forms at shallow depths. The distinct $<160 \mathrm{~m}$ wide interval of widely oriented gouge-
\end{abstract}

filled fractures constitutes an "inner damage zone." This zone is interpreted to extend towards the base of the seismogenic crust given that its width is comparable to (1) the Alpine Fault low-velocity zone detected by fault zone guided waves and (2) damage zones reported from other exhumed largedisplacement faults. In summary, a narrow zone of fracturing at the base of the Alpine Fault's hanging-wall seismogenic crust is anticipated to widen at shallow depths, which is consistent with fault zone flower structure models.

\section{Introduction}

Conceptual models of fault zone structure in the upper crust often invoke a relatively narrow "fault core" that accommodates most displacement, surrounded by a halo of heavily fractured rock termed the "damage zone" (Caine et al., 1996; Chester et al., 1993; Chester and Logan, 1986; Faulkner et al., 2010). These models have been successfully applied in a variety of tectonic settings and for a wide range of fault displacements and exhumation depths (e.g. Choi et al., 2016; Faulkner et al., 2010; Kim et al., 2004; Mitchell and Faulkner, 2009; Savage and Brodsky, 2011). However, the term "damage zone" has been applied by geologists and geophysicists to describe a variety of fault-related features, such as fractures and faults at stepovers and bends (Chester and Chester, 2000; Kim et al., 2004; Mitchell and Faulkner, 2009; 


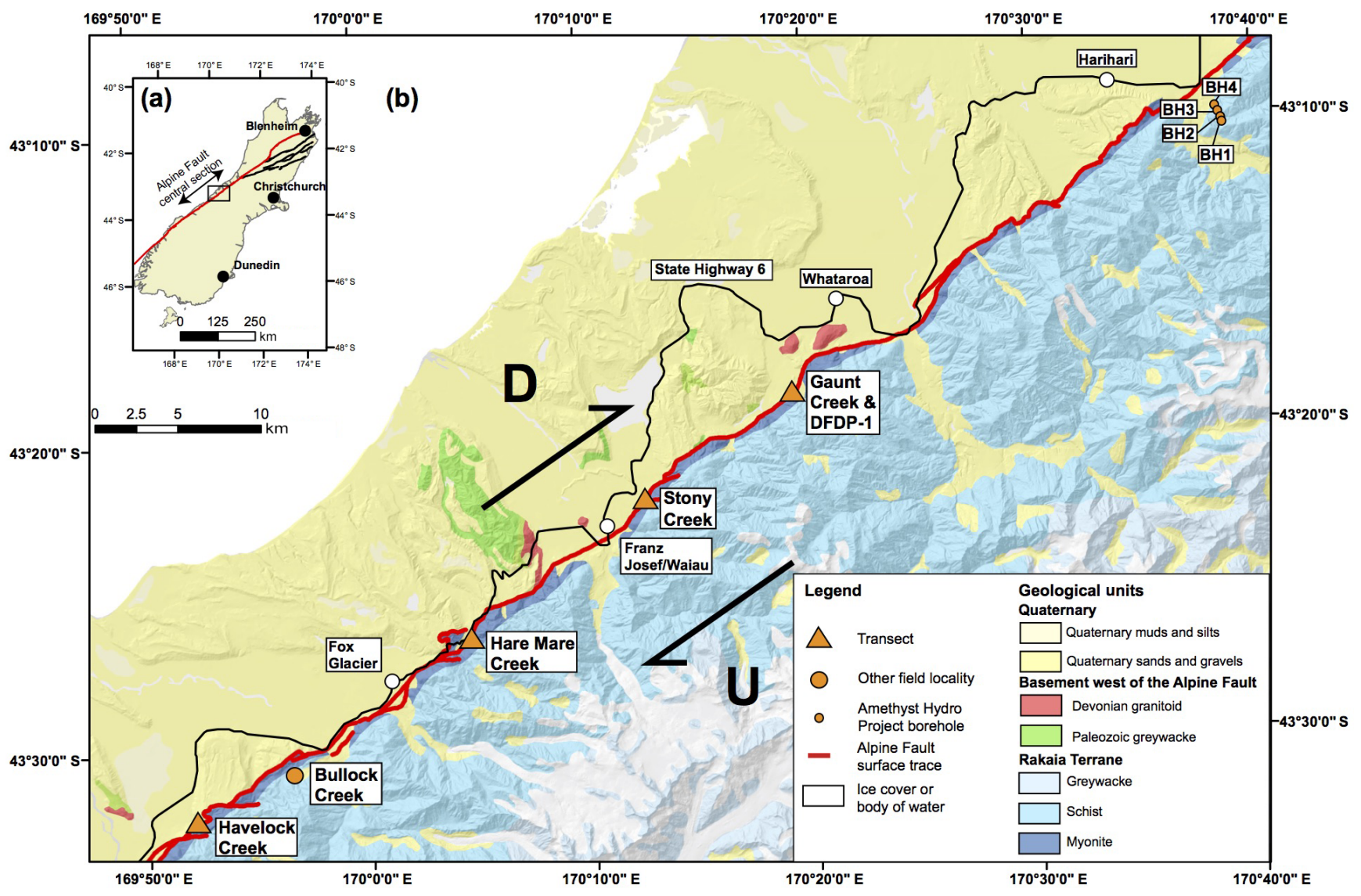

Figure 1. (a) Location map for Alpine Fault (red line) and Marlborough faults (black line) in the South Island of New Zealand. Box shows extent of (b) a location map for the first phase of the Deep Fault Drilling Project (DFDP-1) and Amethyst Hydro Project (AHP) boreholes, and field transects. The generalised underlying geology is derived from the GNS Science 1:250000 QMAP project (Rattenbury and Isaac, 2012) and has been draped over a digital elevation model (Columbus et al., 2011).

Wilson et al., 2003), the volume of inelastic deformation that is induced by dynamic stresses during earthquake rupture propagation (Andrews, 2005; Cowie and Scholz, 1992; Rice et al., 2005; Templeton et al., 2008; Vermilye and Scholz, 1998), and the volume of rock in which earthquake swarms or foreshock and aftershock sequences are localised (Kim and Sanderson, 2008; Savage et al., 2017; Sibson, 1989; Yukutake et al., 2011). Furthermore, though damage zones are typically reported to be $<1 \mathrm{~km}$ wide (Faulkner et al., 2011; Savage and Brodsky, 2011), co-seismic ground shaking can modify fracture permeability many hundreds of kilometres away from the fault source (Cox et al., 2015; MuirWood and King, 1993; O’Brien et al., 2016).

Brittle faults often develop in mylonite sequences or other (e.g. jointed) rocks that contain compositional and mechanical anisotropies (Bistacchi et al., 2012; Chester and Fletcher, 1997; Massironi et al., 2011). Evidence from field studies (Bistacchi et al., 2010; Peacock and Sanderson, 1992), experiments (Donath, 1961; Misra et al., 2015; Paterson and Wong, 2005), and numerical modelling (Chester and Fletcher, 1997) demonstrates that such anisotropy can signif- icantly affect the orientation and density of brittle fractures. Despite this, "fault core-damage zone" models are based largely on field observations from relatively isotropic host rocks, and there have been comparatively few field studies (a notable exception being Bistacchi et al., 2010) that document the influence of mechanical anisotropy on patterns of brittle fracture damage in large-displacement faults.

In this contribution, multiple datasets across a range of scales were used to analyse fracture densities, orientations, and mineral fills across the hanging wall of the Alpine Fault's central section. Measurements from within $25 \mathrm{~m}$ of the Alpine Fault principal slip zones (PSZs) were made from shallow (depths $<130 \mathrm{~m}$ ) drill cores and wireline logs obtained during the first phase of the Deep Fault Drilling Project (DFDP-1). These are combined with field studies at distances $<500 \mathrm{~m}$ from the PSZs and analyses of drill core recovered at $0.7-2 \mathrm{~km}$ from the PSZs during the Amethyst Hydro Project (AHP). Results are then compared to measurements of hydraulic conductivity (Cox et al., 2015; Townend et al., 2017) and geophysical studies (Boese et al., 2012; Chamberlain et al., 2017; Eccles et al., 2015) around the 
Alpine Fault. In doing so, we critically assess the application of "damage zone" models to an active plate-boundary-scale structure. Furthermore, the Alpine Fault rapidly exhumes ductile-to-brittle fault rock sequences from depths of up to $35 \mathrm{~km}$ (Little et al., 2005; Norris and Toy, 2014). Fracturing in its hanging wall therefore overprints a $1-2 \mathrm{~km}$ wide mylonite sequence containing a pervasive foliation (Cooper and Norris, 1994; Norris and Cooper, 1997, 2007; Toy, 2008), and so can provide new insights into the relationships between fracturing and mechanical anisotropy.

\section{Tectonic setting of the Alpine Fault}

The Alpine Fault is a crustal-scale (along-strike extent $\sim 850 \mathrm{~km}$, depth $\sim 35 \mathrm{~km}$ ) transpressive discontinuity accommodating $\sim 70 \%$ of Pacific-Australian plate motion in the South Island of New Zealand (DeMets et al., 1994; Norris and Cooper, 2001, Fig. 1a). This study focuses on the central section between the Toaroha and Martyr rivers (Barth et al., 2013) where it currently accommodates dextral strike slip at a rate of $27 \pm 5 \mathrm{~mm} \mathrm{yr}^{-1}$ and dip slip at a rate of 6-10 $\mathrm{mm} \mathrm{yr}^{-1}$ (Little et al., 2005; Norris and Cooper, 2001).

In the central section at depths greater than $8-12 \mathrm{~km}$, the Alpine Fault accommodates motion via viscous creep across a $>1 \mathrm{~km}$ wide ductile shear zone in which the hanging-wall "Alpine Schist" protolith is progressively mylonitised (Norris and Cooper, 2007; Toy et al., 2010). Shear strains increase with proximity to the Alpine Fault and are recorded by protomylonites, mylonites, and ultramylonites, which occur in spatial sequence towards the fault (Fig. 2; Norris and Cooper, 2003; Reed, 1964; Toy et al., 2008). Foliation in the mylonite sequence is mainly defined by alternating quartzofeldspathic and mica-rich layers (Fig. 2). Bottle-green hornblende-rich metabasic mylonites and purple-dark grey mylonites that are comparatively mica rich are also present. Their presence reflects variations in protolith lithology (Cooper and Norris, 2011; Norris and Cooper, 2007; Sibson et al., 1981; Toy, 2008). As the mylonites in the hanging wall are exhumed to depths of less than $8-12 \mathrm{~km}$, temperatures drop below those at which quartz plasticity occurs and brittle structures start to overprint the mylonitic shear zone (Norris and Cooper, 2007; Toy et al., 2010, 2015). This brittle overprint is reflected in the formation of $\mathrm{a} \sim 20 \mathrm{~m}$ thick layer of green, indurated, and often foliated cataclasite (Allen et al., 2017; Toy et al., 2015), and a $10-50 \mathrm{~cm}$ thick clay-rich PSZ that is preserved adjacent to the currently active fault trace (Boulton et al., 2017, 2012; Ikari et al., 2014; Mitchell and Toy, 2014).

To the first order (i.e. at scales $>10 \mathrm{~km}$ ), the trace of the Alpine Fault is remarkably linear, with an average strike of $055^{\circ}$ (Norris and Cooper, 2007). On the basis of geophysical imaging and measurements of the mylonitic foliation which is thought to parallel the fault - it is estimated to dip at $\sim 45^{\circ}$ in its central section (Sibson et al., 1981; Stern et al., 2007), though this may locally exceed $60^{\circ}$ (Little et al.,
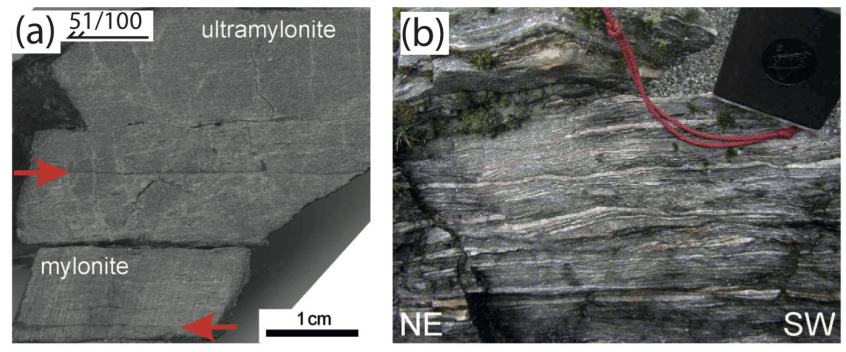

Figure 2. (a) Quartzofeldspathic Alpine Fault ultramylonite that gradually grades to mylonite at the base of the image from Gaunt Creek $\left(43^{\circ} 19^{\prime} 00.62^{\prime \prime} \mathrm{S}, 170^{\circ} 19^{\prime} 32.79^{\prime \prime} \mathrm{E}\right)$. A foliation defined by alternating white quartzofeldspathic bands and dark grey mica bands is hard to distinguish in the ultramylonite but is more apparent in the mylonite. (b) The well-foliated Alpine Fault protomylonite-mylonite transition at Gaunt Creek $\left(43^{\circ} 19^{\prime} 05.11^{\prime \prime} \mathrm{S}\right.$, $\left.170^{\circ} 19^{\prime} 46.16^{\prime \prime} \mathrm{E}\right)$. Compass is $5 \mathrm{~cm}$ wide. Both images were previously presented in Toy (2008).

2005; Toy et al., 2017). At scales of $1-10 \mathrm{~km}$, perturbations in the stress field induced by hanging-wall topography results in segmentation of the Alpine Fault. Segmentation is rooted to depths of $0.5-4 \mathrm{~km}$ and comprises kilometre-long, approximately E-W-striking and steeply dipping strike-slip fault strands, which adjoin NE-SW-striking, gently dipping $\left(\sim 30^{\circ}\right)$ thrust segments (Barth et al., 2012; Langridge et al., 2014; Norris and Cooper, 1995, 2007; Simpson et al., 1994; Upton et al., 2017).

\section{Methods}

\subsection{Fracture orientations from DFDP-1 drill core}

Hanging-wall fracture orientations immediately adjacent to the Alpine Fault's PSZ were assessed through analysis of datasets arising from the first phase of the DFDP-1 (http: //alpine.icdp-online.org, last access: 18 April 2018). DFDP1 successfully sampled the Alpine Fault in two boreholes (DFDP-1A and DFDP-1B, Fig. 3) at depths of less than $150 \mathrm{~m}$ at Gaunt Creek (Fig. 1b, Sutherland et al., 2012). The geophysical properties of the DFDP-1 boreholes were characterised by a full suite of wireline logs (Townend et al., 2013). These were combined with visual descriptions of $\sim 70 \mathrm{~m}$ of core recovered across the two boreholes to construct a lithological classification scheme for DFDP-1 drill core (Fig. 3, Toy et al., 2015).

Abundant fractures were observed in X-ray computed tomography (CT) scans of DFDP-1 drill core (Williams et al., 2016). The true orientations of these fracture were obtained by generating "unrolled" CT images of individual core sections (Mills and Williams, 2017), which are directly analogous to geographically referenced - but lower resolution - borehole televiewer (BHTV) images. Where fractures could be matched between the two images, a rotation could 


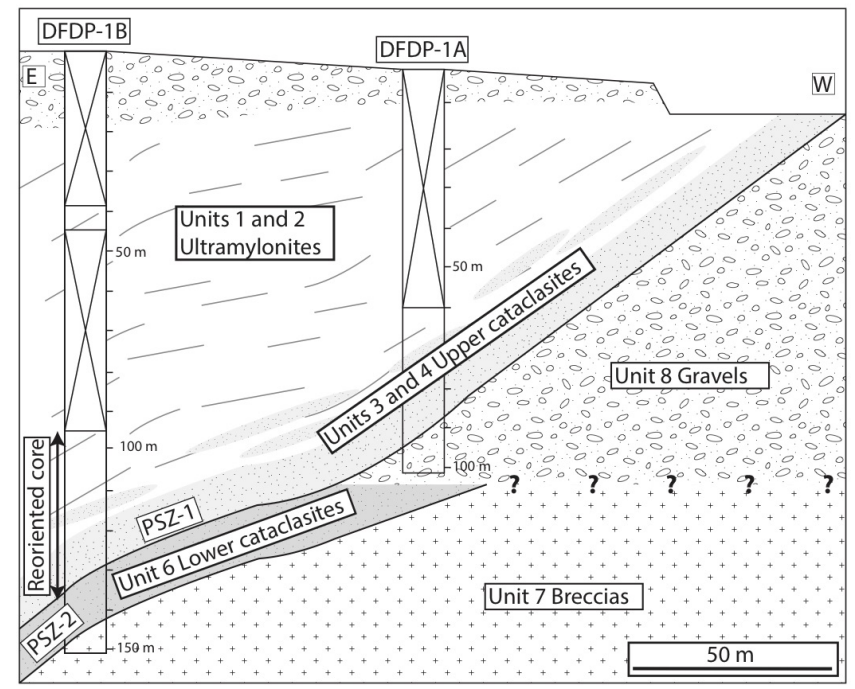

Figure 3. Cross section through the DFDP-1 boreholes, showing interval where reoriented drill core is located. Boxes with diagonal lines depict intervals in the borehole with no core recovery; grey lines represent mylonitic foliation. Modified from Sutherland et al. (2012), with lithological units previously defined by Toy et al. (2015).

be derived to transform all fracture orientations in the CT scans from a local core reference frame to their true geographic orientation (Fig. 4). Depending on the number of fractures matched, the core was rotated with a high, moderate, or low degree of confidence. In DFDP-1A, the quality of BHTV imaging was insufficient to attempt matching fractures, whereas in the Alpine Fault's relatively intact footwall (Townend et al., 2013), too few fractures (less than one fracture per core section) could be imaged to attempt core reorientation. Therefore, the true orientation of fractures was only determined for the depth interval 94-126 $\mathrm{m}$ in the DFDP-1B borehole (Fig. 3). Given the orientation of the PSZ-1 (which separates hanging-wall and footwall cataclasite) sampled in DFDP-1 (015/43 E; Townend et al., 2013), this spans an orthogonal distance of $\sim 25 \mathrm{~m}$. A full methodology is provided in Appendix A, the rotations applied to DFDP-1 core sections are listed in Table S1 in the Supplement, and a complete CTBHTV image comparison is given in Williams et al. (2017b).

\subsection{Field observations of fracture orientations and densities}

At orthogonal distances of up to $150-250 \mathrm{~m}$ from the PSZs, fracture orientations and densities were measured in four creeks (Gaunt Creek, Stony Creek, Hare Mare Creek, and Havelock Creek; Fig. 1b) that cut across the hanging-wall sequence approximately perpendicular to the main fault trace (Fig. S1). Along each creek, fracture orientations and densities were measured at three or four stations. This information was also gathered at approximately $500 \mathrm{~m}$ from the
Alpine Fault at Bullock Creek (Fig. 1b). Each creek transect cuts across a thrust segment of the Alpine Fault, so the orthogonal distance between the measuring stations and the PSZs was calculated assuming a fault dip of $30^{\circ}$ (Norris and Cooper, 1995, 1997). The mylonite lithology for each station was classified using the scheme presented by Toy (2008).

The outcrops encountered along these transects are typically subvertical and may be covered by debris except at their bases where they are frequently cleaned by flood events (Fig. S2 in the Supplement). They are therefore poorly suited for fracture density analysis using circular scanlines (e.g. Mauldon et al., 2001). Instead, the fracture density was calculated from the number and orientation of fractures that intersected a linear transect along the base of each outcrop (Priest, 1993; Schulz and Evans, 2000). This technique has the tendency to under-sample fractures oriented at low angles to the scanline. Therefore, a weighting $(w)$ factor calculated using a modified version of the Terzaghi correction (Massiot et al., 2015; Terzaghi, 1965) was applied to each fracture, and results are shown as "corrected" fracture density.

\subsection{Fracture orientations in the Amethyst Hydro Project boreholes}

The AHP was developed to divert water from the Amethyst Ravine down a $1040 \mathrm{~m}$ long tunnel to a powerhouse on the floodplain of the Wanganui River. Prior to the main phase of tunnelling, four exploratory boreholes (BH1-4; Figs. 1b and S3) were completed between 2005 and 2006, resulting in the recovery of $\sim 890 \mathrm{~m}$ of drill core at depths of 50-200 m. The boreholes are situated 1-2 km southeast of a thrust segment of the Alpine Fault, where it may conceivably dip at a range of 30-60 (Norris and Cooper, 1995; Toy et al., 2017). The drill cores are therefore at orthogonal distances of $\sim 0.7$ $2.0 \mathrm{~km}$ from the PSZs.

To provide a dataset analogous to the DFDP-1 CT scans, a total of $31.9 \mathrm{~m}$ of drill core from the AHP boreholes was CT scanned at the Southern Cross Hospital in Wellington, New Zealand. Initial descriptions of the drill core found that the rock quality designation (RQD, the percent of intact core lengths $>100 \mathrm{~mm}$ per $1 \mathrm{~m}$ of drill core) varied considerably due to intense fracturing adjacent to the Tarpot Fault and other minor faults that intersect the AHP boreholes (McCahon, 2006; Savage, 2013). However, for practical reasons, scanning was focused on intervals of high RQD (Fig. S3). The CT scanner was operated at $100 \mathrm{~mA}$ and an X-ray tube voltage of $120 \mathrm{kVp}$. Slice spacing was $1.25 \mathrm{~mm}$, field of view was $250 \mathrm{~mm}$, and the image size was $512 \times 512$ pixels. Therefore, the size of one voxel is $0.488 \times 0.488 \times 1.25 \mathrm{~mm}$ in the $x, y$, and $z$ directions, respectively. Reconstruction of two-dimensional CT slices into three-dimensional images of the drill core was performed using OsiriX Imaging Software (http://www.osirix-viewer.com/, last access: 18 April 2018). 
(a)

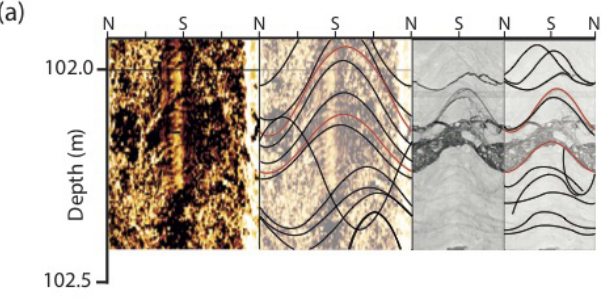

(b)

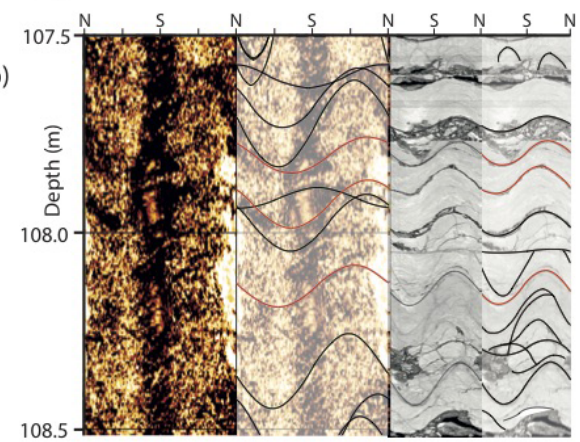

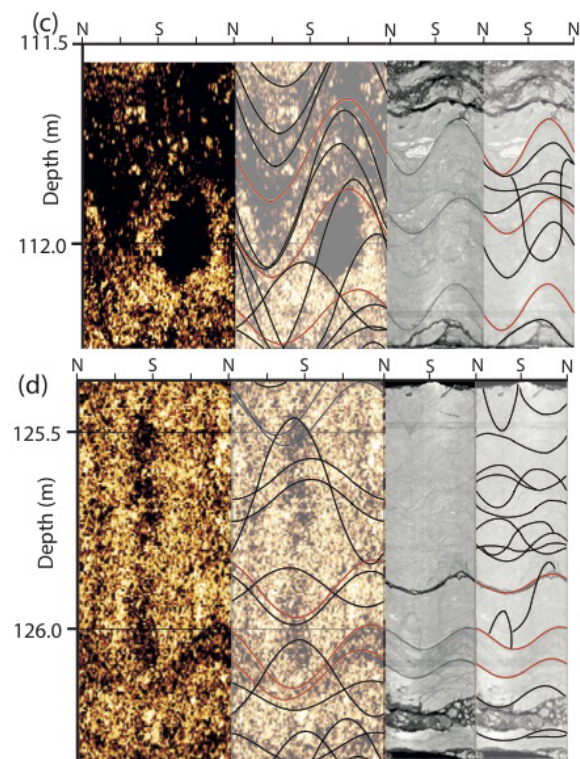

Figure 4. Examples of matching structures between BHTV images and unrolled CT images. In each image, the first two columns are the BHTV amplitude image, without and with interpretations, respectively, whilst the third and fourth columns depict the unrolled CT image over the same interval, also without and with interpretations. Fractures that have been traced in red indicate those that were matched to re-orientated core.

AHP drill core was not oriented. However, the orientation of the schistosity is noted in the drill-core logs to an accuracy of $\pm 5^{\circ}$ (McCahon, 2006), where it is consistent with the schistosity orientation measured in the Amethyst Tunnel itself (Savage, 2013). It can thus be used as a reference to reorient drill-core CT scans back into a geographic reference frame. For $\mathrm{BH} 2$ and $\mathrm{BH} 3$ drill cores, which are vertical, this required only a single transformation. For the inclined $\mathrm{BH} 1$ and $\mathrm{BH} 4$ drill cores, this required first rotating the core with respect to the foliation. These orientations were then corrected for the inclination of the drill core using the Planes from Oriented and Navigated Drillcore (POND) Excel spreadsheet (Stanley and Hooper, 2003).

\subsection{Statistical analysis of fracture orientations}

The clustering intensity of fracture orientations was quantified using the resultant vector method of Priest (1993), where the vector for each fracture was weighted by the Terzaghi correction for misorientation bias (Massiot et al., 2015; Terzaghi, 1965). This analysis was performed only for the DFDP-1 and AHP datasets, which sampled a large population $(>100)$ of fractures. Field-measuring stations sampled too few $(<30)$ fractures to reliably perform this analysis, and so their clustering is described in a qualitative sense only.

\section{Results}

\subsection{Fracture orientations in DFDP-1 drill core within $25 \mathrm{~m}$ of the Alpine Fault}

In the DFDP-1 CT images, a total of 637 fractures were rotated into their true geographic orientation where they show a weak cluster about the orientation of the foliation and Alpine Fault PSZs at Gaunt Creek (015/43 E, Fig. 5a, Appendix B; Townend et al., 2013). Features in DFDP-1B BHTV images are also aligned about this orientation but with a higher cluster intensity than fractures noted in the CT images (Fig. 5b, Table 1). This may reflect (1) features observed at the resolution of the BHTV are more likely to be aligned subparallel to the fault plane and foliation than those visible in CT, and/or (2) some of the planar features identified from the BHTV images were the mylonitic foliation itself. The clustering of fractures hosted in foliated ultramylonites and cataclasites (units 1, 2, and 4 of Toy et al., 2015) is the same as fractures hosted in relatively homogenous unfoliated cataclasites (unit 3 of Toy et al., 2015; Fig. 5c and d, Table 1). We also observed no clear relationships between fracture fill (Table 1 of Williams et al., 2016) and fracture orientation (Fig. 5a).

\subsection{Fracture orientations, densities, and fill in field transects within $500 \mathrm{~m}$ of the Alpine Fault}

The orientations and densities of fractures observed in the four field transects are summarised in Fig. 7. In these transects, similar fractures to those observed in the CT scans of DFDP-1 core are identified (Fig. 8). Total fracture density 


\title{
(a) All fractures in reoriented CT images
}

\author{
(b) Features in BHTV images \\ over depth interval of reoriented \\ CT images
}
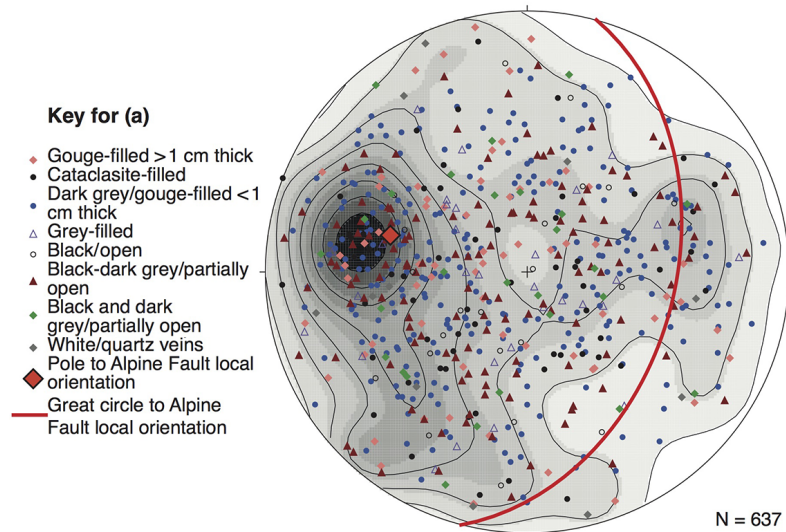

(c) Foliated units

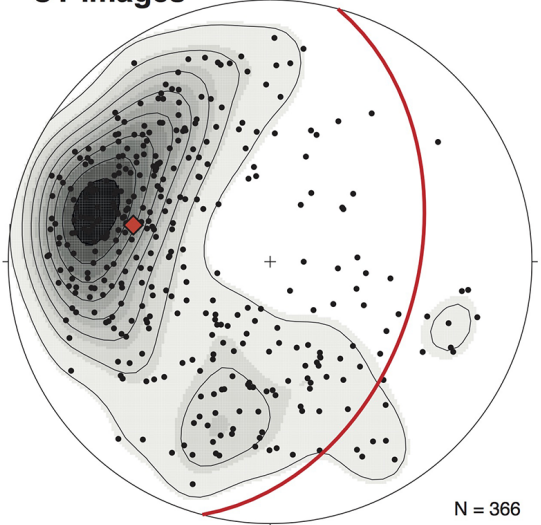

(d) Unfoliated units
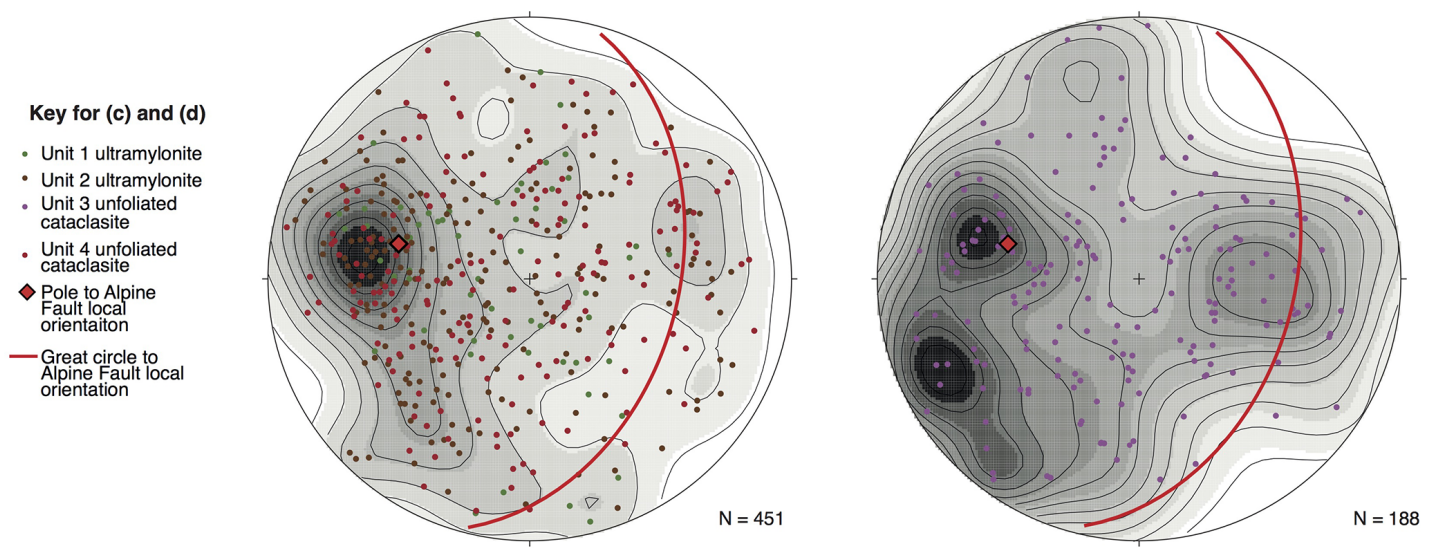

Figure 5. Lower hemisphere equal area stereoplots depicting orientation of fractures in DFDP-1. Contouring on stereoplots was applied to poles that are weighted depending on their orientation correction $w$ (see Sect. 3.2) and that are rounded to the nearest whole number. Contours were then generated for the weighted poles using a probability distribution calculated by a Kernel function in the RFOC package for R (Lees, 2014). Great circle represents orientation of Alpine Fault plane and foliation at DFDP-1 site (Townend et al., 2013). (a) Orientation of all fractures that were reoriented by matching structures between unrolled CT images and BHTV images, sorted by fracture type (Williams et al., 2016). (b) Orientation of features recognised in the BHTV images over the interval of reoriented core (94-126 m in DFDP-1B). Fracture orientations extracted from reoriented DFDP-1 CT images in (c) foliated units and (d) unfoliated units, using the DFDP-1 lithological classification scheme (Toy et al., 2015).

Table 1. Clustering analysis of the different fracture datasets documented in this study, using the resultant vector methodology outlined by Priest (1993). DFDP-1 foliated units comprise ultramylonites and foliated cataclasites (units 1, 2, and 4 of Toy et al., 2015). DFDP-1 unfoliated units comprise unfoliated cataclasites (unit 3 of Toy et al., 2015). The resultant vector orientation for each dataset, which has been converted to spherical coordinates, is also reported. See text for full details. The term "s.f." indicates significant figures.

\begin{tabular}{lrrrr}
\hline & $\begin{array}{r}\text { Number of } \\
\text { fractures }\end{array}$ & $\begin{array}{r}\text { Resultant plane } \\
\text { dip direction }\end{array}$ & $\begin{array}{r}\text { Resultant } \\
\text { plane dip }\end{array}$ & $\begin{array}{r}\text { Resultant vector length } \\
\text { (cluster intensity, 2 s.f.) }\end{array}$ \\
\hline All reoriented DFDP-1 CT fractures & 637 & 80 & 58 & 0.58 \\
Reoriented DFDP-1 CT fractures, foliated units & 451 & 87 & 58 & 0.58 \\
Reoriented DFDP-1 CT fractures, unfoliated units & 188 & 71 & 61 & 0.58 \\
DFDP-1B BHTV features (depth interval 94-126 m) & 365 & 103 & 47 & 0.72 \\
AHP fractures & 239 & 164 & 58 & 0.76 \\
\hline
\end{tabular}


(a)

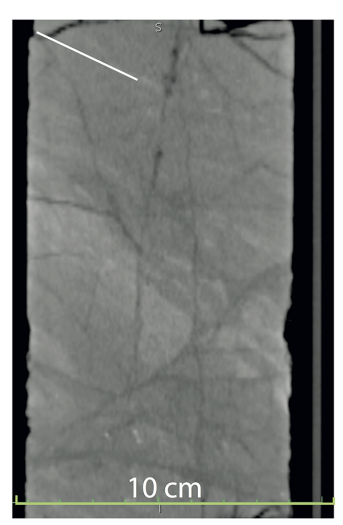

CT number key: $500 \quad 2250 \quad 4000$ (b)
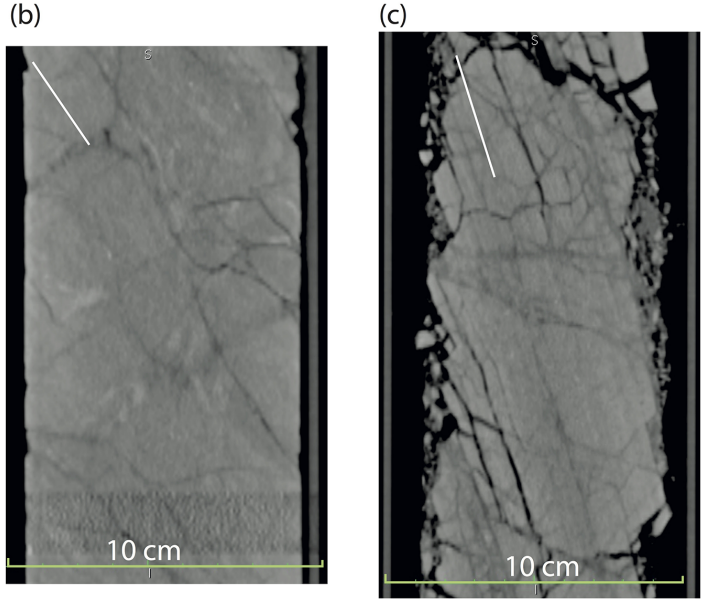

Figure 6. The relationship between foliation and fracture orientations in Alpine Fault ultramylonite, as observed in 2-D CT image slices of DFDP-1 drill core. Intervals are (borehole, core section and run, depth interval) (a) DFDP-1A 55-1 75.45-75.62 m, (b) DFDP-1B 351 102.49-102.64 m, and (c) DFDP-1B 25-2, 44.80-45.20 m. In panels (a) and (b), fractures tend to cross-cut the ultramylonitic foliation (orientation represented by white line in the top left corner of each image). (c) Fractures show a greater preference to be aligned parallel to the foliation. Note that panel (c) was previously shown in Williams et al. (2016) and is not included in the reorientation analysis in Fig. 5, as there was no BHTV imagery for this interval.

in the transects varies between 3 and 30 fractures $\mathrm{m}^{-1}$, and there is no clear decrease in fracture density with increasing distance from the Alpine Fault in any of the transects (Fig. 7a). Gouge-filled fractures (Fig. 8a-c) are observed at all distances from the Alpine Fault but are relatively abundant ( $>1$ fracture $\mathrm{m}^{-1}$, Fig. 7a, Table S2) within $100-160 \mathrm{~m}$ of the PSZs (Fig. 7a). The thicker gouge-filled fractures $(>1 \mathrm{~cm})$ commonly juxtapose different lithologies or offset markers (Fig. 8d-f). Thinner gouge-filled fractures $(<1 \mathrm{~cm})$ are localised to within $160 \mathrm{~m}$ of the Alpine Fault. Open fractures (Fig. 8g-i) are present at all stations, though are most prevalent at those furthest from the fault (Fig. 7b).

The composition of the mylonites can also affect fracture density. When they are juxtaposed together, micaceous mylonites and ultramylonites are observed to contain relatively high densities of gouge-filled fractures compared to quartzofeldspathic mylonites and ultramylonites (Fig. 9). Localities that showed the widest range in fracture orientations tend to be less than $160 \mathrm{~m}$ from the PSZs within the ultramylonites (Fig. 7b). Within mylonite units, fracture orientations tend to be more aligned to the foliation (Fig. 7b), although gouge-filled fractures can sometimes cut across it (e.g. Bullock Creek).

\subsection{Fractures in AHP drill core, $0.7-2.0 \mathrm{~km}$ from the Alpine Fault}

The AHP sampled grey, well-foliated Alpine Schist (Fig. 10), a subgroup of the Haast Schist (textural zones III-IV, Turnbull et al., 2001; Cox and Barrell, 2007). Fracture orientations are clustered about the orientation of the host rock schistosity in agreement with the findings during initial drillcore descriptions and observations within the Amethyst Tunnel itself (Fig. 11; McCahon, 2006; Savage, 2013). The clustering of these fracture orientations is stronger than in the DFDP-1 datasets (Table 1). Fractures that cut across the schistosity are most frequent in BH4 (Figs. 10d and 11).

Though fractures are predominantly open, it is conceivable that the original fill may have been lost during the subsequent core handling processes. This means that standard schemes to differentiate between natural and induced fractures $(\mathrm{Ku}-$ lander et al., 1990; Williams et al., 2016) cannot be applied to this dataset. Nevertheless, some open fractures must be natural as they show alteration haloes (Fig. 10a) implying that they were once conduits for fluid flow. Furthermore, packer tests conducted in these boreholes indicate hydraulic conductivities of $\sim 10^{-6}-10^{-5} \mathrm{~ms}^{-1}$, which is equivalent to permeabilities of $10^{-13}-10^{-12} \mathrm{~m}^{2}$ (Cox et al., 2015; McCahon, 2006). No permeability measurements have been made in the schist protolith at greater distances from Alpine Fault; however, these measurements are orders of magnitude higher than what has been reported in other metamorphic rock terranes $\left(\sim 10^{-20}-10^{-17} \mathrm{~m}^{2}\right.$; Manning and Ingebritsen, 1999) and for typical continental crust $\left(\sim 10^{-17} \mathrm{~m}^{2}\right.$; Townend and Zoback, 2000). 

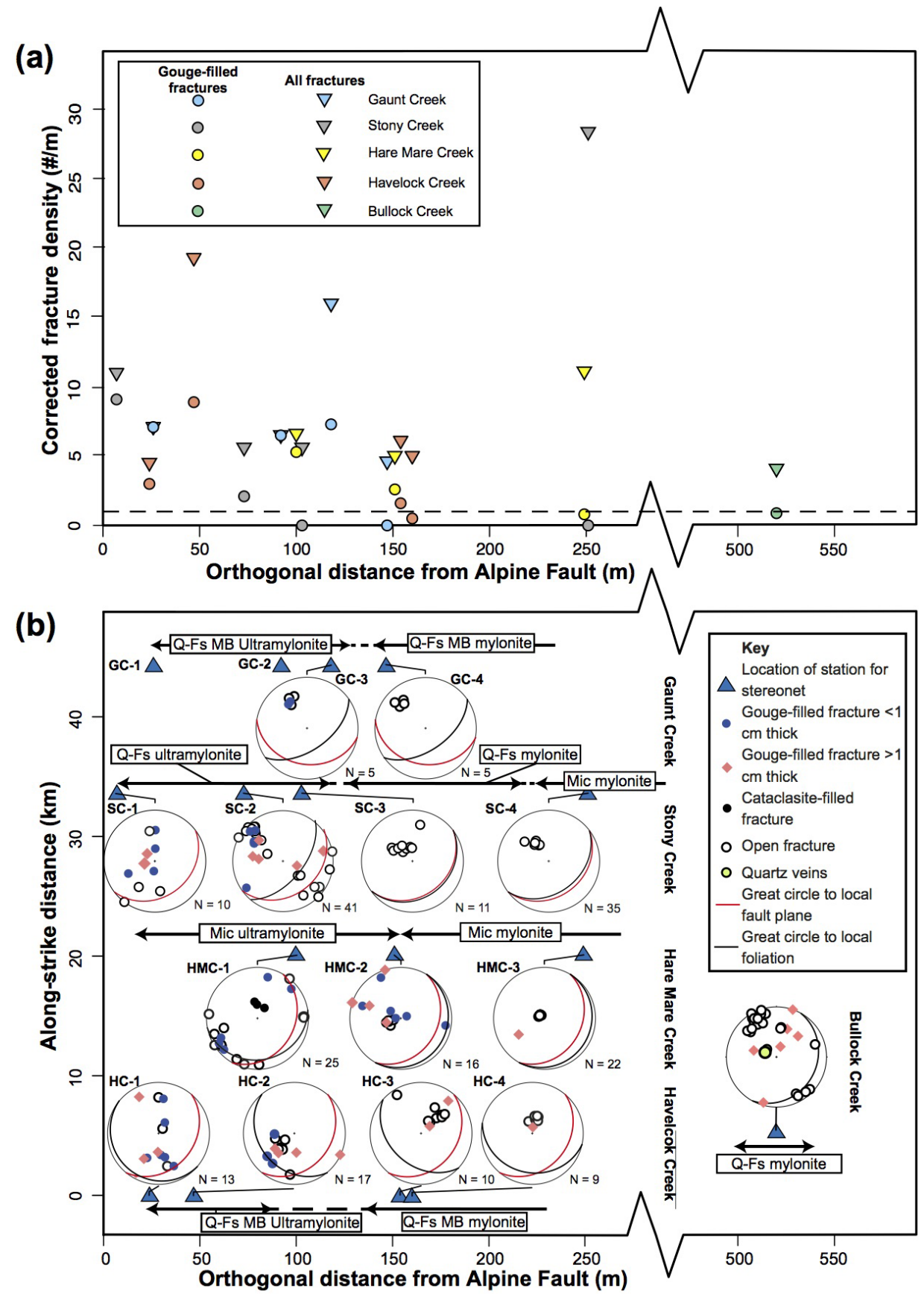

Figure 7. (a) Corrected fracture density at all stations for gouge-filled fractures and all fractures. The dashed line indicates a corrected fracture density of 1 fracture $\mathrm{m}^{-1}$. No orientation data were collected at Gaunt Creek stations 1 and 2, so fracture density is calculated from the two perpendicular transects. (b) Compilation of stereoplots for fracture orientations at each field station. Stations have been plotted as a function of distance from the fault and distance along strike (with respect to Havelock Creek) along within fault rock lithologies (Toy, 2008). Dashed lines indicate gradational or obscured lithological boundaries. Qf:, quartzofeldspathic; MB: metabasic; Mic: micaceous. For field cross sections and location of stations, see Fig. S1 and Table S2. 


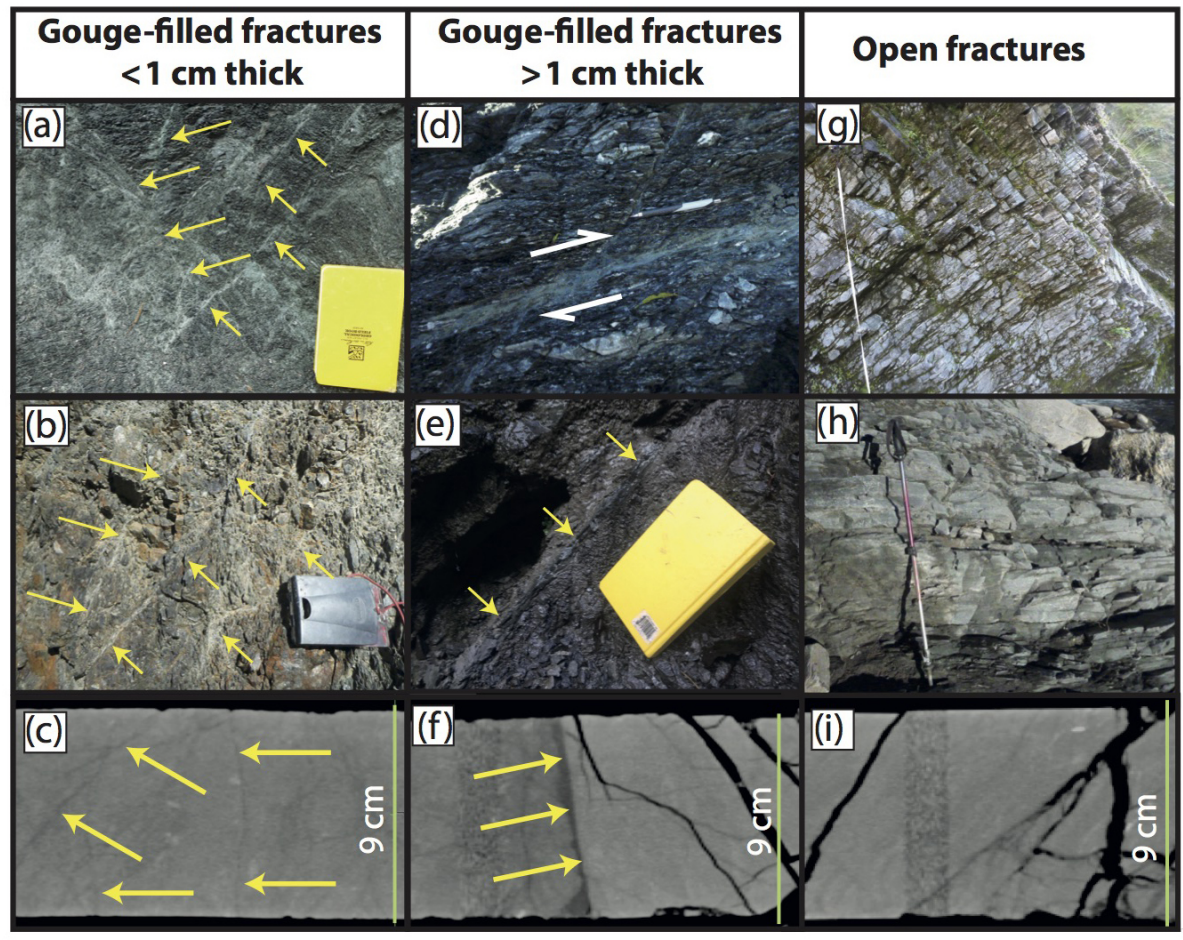

Figure 8. Examples of the three main types of fractures observed in the field around the Alpine Fault, and correlative fractures in DFDP-1 CT scans. (a-c) Thin gouge-filled fractures (yellow arrows) have a range of orientations and are found exclusively within $160 \mathrm{~m}$ from the fault. They are equivalent to type iii fractures from Williams et al. (2016). (d-f) Thicker gouge- and cataclasite-filled fractures are equivalent to type $\mathrm{i}$ and ii fractures of Williams et al. (2016) and may be observed at all distances from the Alpine Fault. Offset markers can be observed across these fractures (e.g. the vein indicated by the pen and white arrows in panel d). (g-i) Open fractures are mainly foliation parallel. Equivalent to type $v$ fractures of Williams et al. (2016). Location of field photos: (a) Waikukupa thrust $\left(43^{\circ} 26^{\prime} 34.7^{\prime \prime} \mathrm{S}, 170^{\circ} 04^{\prime} 10.9^{\prime \prime} \mathrm{E}\right)$,

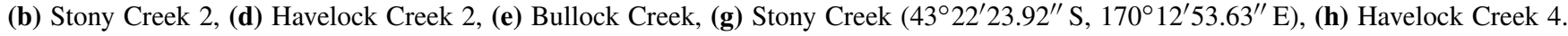
Compass clinometer is $8 \mathrm{~cm}$ and yellow notebook is $20 \mathrm{~cm}$ in length. Measuring tape in panel (e) is $1.1 \mathrm{~m}$ long; walking pole in panel (g) is $1 \mathrm{~m}$ in length. DFDP-1 CT scan intervals: (c) DFDP-1B 56-2 125.35-125.49 m, (f) DFDP-1B 35-1 102.00-102.15 m, (i) DFDP-1B 33-2 99.45-99.60 m.

\section{Discussion}

\subsection{Fracture orientations in anisotropic wall rocks in the Alpine Fault hanging wall}

Two styles of fracturing are evident in the foliated Alpine Fault cataclasite, mylonite, and schist sequence (Fig. 12). Within DFDP-1 drill core, fractures are predominantly gouge-filled and exhibit a range of orientations (Figs. 5 and 6) with only a small proportion (11\%) of fractures in foliated cataclasites and ultramylonites clearly foliation parallel (Williams et al., 2016). However, in schists sampled by the AHP drill core, the fractures are more clustered about the foliation than in DFDP-1 drill core (Fig. 11, Table 1). The difference in fracture clustering between the DFDP-1 and AHP drill cores is qualitatively replicated by the field transects, where fractures show variable orientations immediately adjacent to the Alpine Fault but are typically foliation parallel at the sites furthest from the fault (Fig. 7). Furthermore, field transects show that the variably oriented fractures have a gouge fill, whilst foliation-parallel fractures further from the fault tend to be open (Figs. 7 and 8).

Experimental studies on foliated rocks demonstrate that mechanical anisotropy will exert the greatest control on rock failure when (1) the angle between the maximum principal stress $\left(\sigma_{1}\right)$ and the anisotropy $(\alpha)$ is $\sim 30^{\circ}$, (2) confining pressure is low ( $<35 \mathrm{MPa})$, and (3) the mechanical "strength" of the anisotropy is high (Donath, 1961; Misra et al., 2015; Nasseri et al., 2003; Paterson and Wong, 2005). The first factor can be approximated for the Alpine Fault given the mylonite's average orientation of 055/45SE (Norris and Cooper, 2007) and the stress tensor orientation within the surrounding crust, determined from focal mechanisms of microseismicity in the fault's hanging wall (Boese et al., 2012). This yields a value of $\alpha$ of approximately $44^{\circ}$, when measured in the plane containing the maximum and minimum principal stresses. This can be considered an intermediate value of $\alpha$, since in deformation experiments fractures may form parallel or non-parallel to the foliation depending on the combination 




Figure 9. Field observations of changes in fracture density at lithological contacts. (a, b) Intervals of micaceous and metabasite mylonite containing a relatively high proportion of gouge-filled fractures (denoted by yellow arrows) compared to interlayered quartzofeldspathic mylonite. (c) Transition from micaceous mylonite to quartzofeldspathic mylonite coincides with furthest extent of intensive gouge-filled fractures, as shown by yellow arrows in panel (d). Taken at (a) Gaunt Creek 1, (b) Havelock Creek 2, (c, and d) Hare Mare Creek 3. Compass clinometer is $8 \mathrm{~cm}$ and yellow notebook is $20 \mathrm{~cm}$ in length.

of confining pressure and lithology (Donath, 1961; Nasseri et al., 2003; Paterson and Wong, 2005).

Foliation-parallel fractures are least common in the ultramylonites and foliated cataclasites. Indeed, in the DFDP-1 datasets, there is no difference in fracture clustering between foliated and unfoliated units (Table 1). Lithology may control mechanical anisotropy depending on mineralogy, porosity, grain size, and the nature of the foliation surfaces (Donath, 1961; Nasseri et al., 2003). It is notable that phase mixing and grain size reduction in the ultramylonites reduces the intensity of the foliation, compared to the relatively coarsegrained schists, protomylonites, and mylonites (Fig. 2; Norris and Cooper, 2007; Toy et al., 2010, 2008). These data suggest that this lithological change could have a marked effect on the orientation of fractures. Compositional variations between relatively quartzofeldspathic and relatively micaceous mylonites can also influence the density of frac- tures (Fig. 9). These observations highlight that fracturing in the upper crust may be influenced by lithological variations developed within an underlying linked, and synkinematic, shear zone. However, at other localities (e.g. Stony Creek, Fig. 7), variations in dominant fracture characteristics are confined within units of similar composition and texture. This suggests that variations in confining pressure may also be important in controlling the relationship between fractures and foliation, as discussed in the next section.

\subsection{Fracture damage around the Alpine Fault}

Field transects across the Alpine Fault's hanging wall show that fracture density remains roughly constant (>3.5 fractures $\mathrm{m}^{-1}$, corrected for orientation bias) for at least $500 \mathrm{~m}$ from the fault (Fig. 7a). Furthermore, the AHP (Cox et al., 2015) and DFDP-2B boreholes (Sutherland et 
(a)

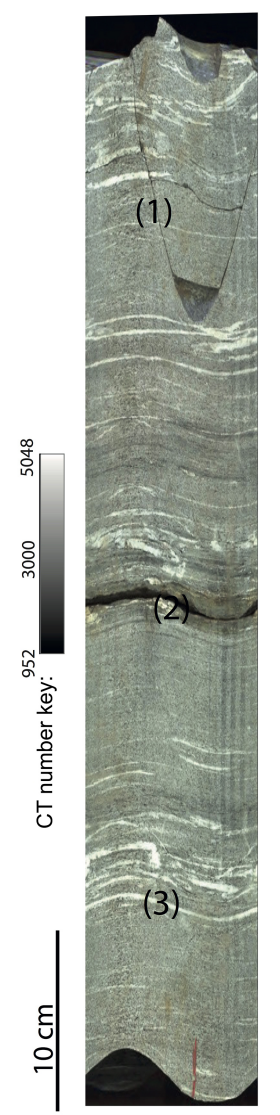

(b)

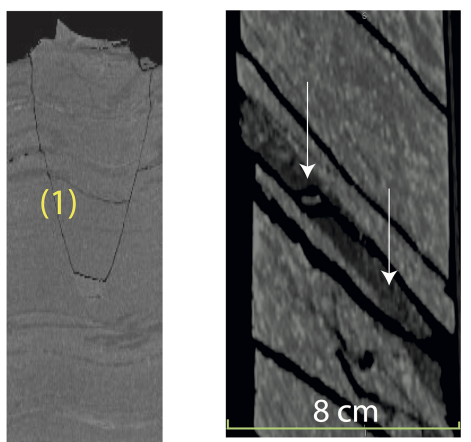

(d)

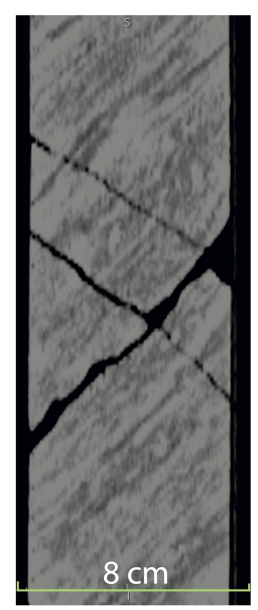

Figure 10. Fractures in the AHP drill core. Unrolled images of AHP drill core (BH1 45-2, 124.3-124.9 m) taken by (a) DMT core scanner and (b) generated from a CT image. (1) Identifies fracture cutting across foliation, (2) foliation-parallel fracture with alteration halo, (3) foliation defined by quartzofeldspathic bands that have low CT numbers. (c, d) Core-axial parallel CT image slices of AHP drill core. In panel (c), white arrows point to a "crush zone" subparallel to foliation (BH2 75-2, 155.92-156.04 m). Panel (d) shows more variable fracture orientations identified in BH4 (section 70-4, 196.62-196.80 m).

al., 2017; Townend et al., 2017) demonstrate an interval of enhanced permeability $\left(10^{-16}-10^{-13} \mathrm{~m}^{2}\right)$ that extends for at least $2 \mathrm{~km}$ into the Alpine Fault's hanging wall. Permeability in this rock mass is controlled by open fractures (Cox et al., 2015; Sutherland et al., 2017; Townend et al., 2017) that are generally foliation parallel (Massiot, 2017), and so directly analogous to the fractures sampled in the field (Fig. 8g-i) and in AHP drill core (Fig. 10). Conventional definitions of fault structure, that use fracture density and permeability as criteria for damage zone width (e.g. Berg and Skar, 2005; Caine et al., 1996; Faulkner et al., 2010; Savage and Brodsky, 2011; Schulz and Evans, 2000), would therefore suggest that the Alpine Fault's damage zone extends for at least $500 \mathrm{~m}$, and possibly $2 \mathrm{~km}$, into its hanging wall.

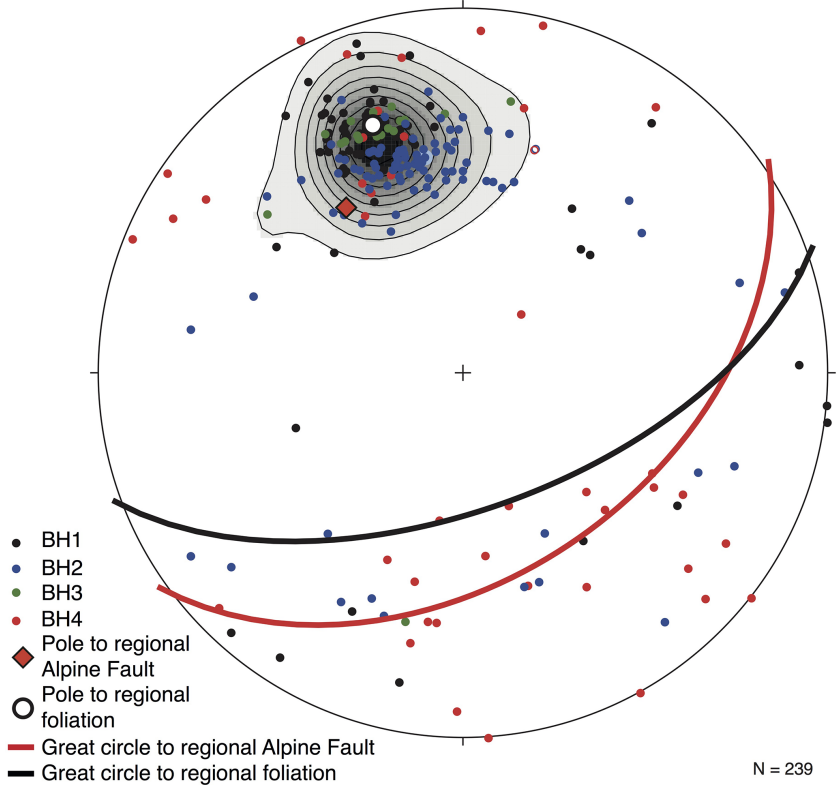

Figure 11. Equal area lower hemisphere projection of fracture orientations recognised in CT scans of AHP drill core separated by a borehole. Contours are plotted with weighted poles (see Fig. 5).

Nevertheless, within the field transects we also note a distinct interval adjacent to the Alpine Fault's PSZs that contains a relatively high density of gouge-filled fractures $\left(>1 \mathrm{fracture}^{-1}\right.$, Fig. 7a). The width of this interval is $<147$ m (i.e. station 4) from the PSZs at Gaunt Creek, $<103 \mathrm{~m}$ at Stony Creek (i.e. station 3), $<151 \mathrm{~m}$ at Hare Mare Creek (at station 2, Fig. 8c), and $<160 \mathrm{~m}$ at Havelock Creek (i.e. station 4). These width estimates are based on assumption that the Alpine Fault dips at $30^{\circ}$ below the measuring stations (see the methods section). However, the fault dip may locally vary (for example, the fault dip sampled by DFDP-1 was $43^{\circ}$; Townend et al., 2013), and there is also uncertainty in the depth extent of its near-surface segmentation (Barth et al., 2012; Norris and Cooper, 1995; Upton et al., 2017). Nevertheless, even if the fault dipped at $45^{\circ}$ (Norris and Cooper, 2007) beneath the measuring stations, the zone of higher-density gouge-filled fractures would be $<205 \mathrm{~m}$ wide (Table S3) and so is still appreciably closer to the Alpine Fault than the intervals sampled by the AHP and DFDP-2 boreholes.

It is this $\sim 100-160 \mathrm{~m}$ wide interval with a high density of gouge-filled fractures that Norris and Cooper (1997, 2007) interpreted as the extent Alpine Fault's central section hanging-wall damage zone. Furthermore, the width of this zone is comparable to damage zone widths estimated elsewhere on the Alpine Fault (e.g. Barth et al., 2013, along the southern section; Wright, 1998, at the northern end of the central section, Fig. 13a) and to other crustal-scale fault zones that have accommodated hundreds of kilometres of 


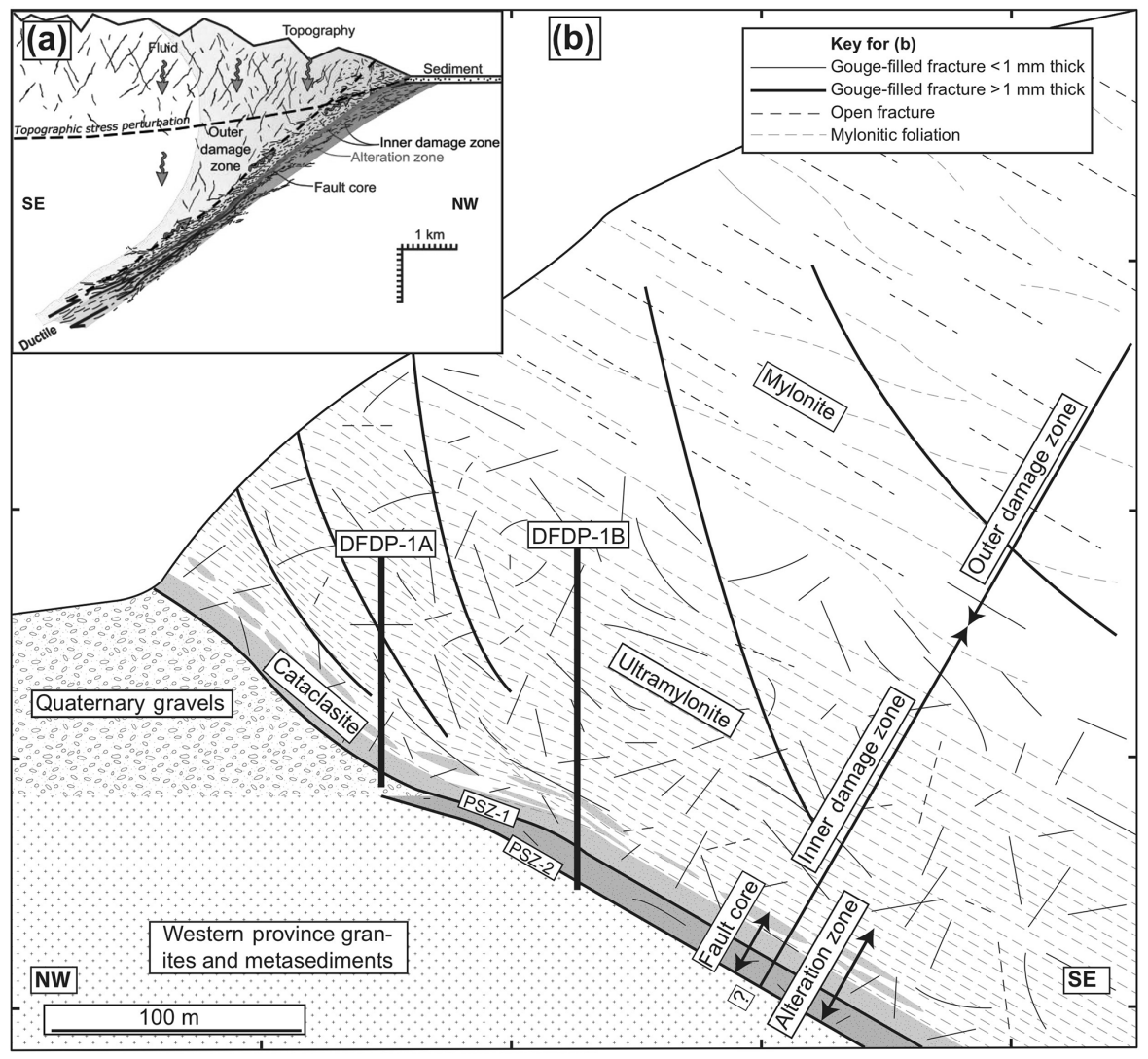

Figure 12. Schematic cross sections through the Alpine Fault illustrating its hanging-wall structure. (a) Crustal-scale cross section illustrating the flower-shaped geometry of the outer damage zone (after Townend et al., 2017). (b) A thrust section within the central section of the Alpine Fault, depicting fracture network, its relationship to foliation, and the distribution of subsidiary faults. Respective position of DFDP-1 boreholes is also shown. Constructed from cross sections previously presented in Norris and Cooper (2007) and Sutherland et al. (2012).

displacement (Fig. 13b; Faulkner et al., 2011; Savage and Brodsky, 2011).

Interpretations of damage zone width within the Alpine Fault's hanging wall may therefore differ by an order of magnitude depending on what criteria are used. To reconcile this, Townend et al. (2017) suggested that the $\sim 2 \mathrm{~km}$ wide interval of enhanced permeability and foliation-parallel fracturing can be considered as an "outer damage zone" (Fig. 12). Fractures within this zone may have formed by co-seismic shaking and slip on critically stressed fractures (Cox et al., 2015; Townend et al., 2017), or by the release of confining pressure (Engelder, 1985; Price, 1959; Zangerl et al., 2006) during rapid exhumation $\left(6-9 \mathrm{~mm} \mathrm{yr}^{-1}\right)$ of the hanging wall (Little et al., 2005; Tippett and Kamp, 1995). Rare gougefilled fractures $\left(<1\right.$ fracture $\left.\mathrm{m}^{-1}\right)$ in this interval (e.g. Fig. 8e) may also be the structures accommodating the diffuse, low to moderate magnitude $\left(M_{\mathrm{W}}<6\right)$ seismicity that has been recorded in a $\sim 5 \mathrm{~km}$ wide zone within the Alpine Fault's hanging wall (Boese et al., 2012; Chamberlain et al., 2017; Eberhart-Phillips, 1995).

Conversely, the $<160 \mathrm{~m}$ wide zone with a relatively high density of gouge-filled fractures defines a narrower "inner damage zone" (Fig. 12; Townend et al. 2017). Microstructural and compositional analysis of these fractures indicates that they formed in response to wear and shearing of the wall rock and were subsequently mineralised due to circulation of hydrothermal fluids (Warr and Cox, 2001; Williams et al., 2017a). Offset markers across gouge-filled fractures (particularly those $<1 \mathrm{~cm}$ thick) are rarely observed in DFDP-1 core and field transects, but where they are present, reverse offset is most frequently noted (Fig. 8d; Norris and Cooper, 1997; Toy et al., 2015). "Gouge-filled shears" that accommodated strike slip (Norris and Cooper, 1997), normal dip slip (Cooper and Norris, 1994), or a combination of both (Barth et al., 2012) have also been observed.

Cooper and Norris (1994) interpreted that dip-slip fractures facilitated imbrication, tectonic thickening, and rotation of Alpine Fault thrust sheets as they moved across the irregular topography of the footwall gravels. Dextral shears are interpreted to reflect the partitioning of strike-slip movement away from shallowly dipping PSZs (Barth et al., 2012). The diverse range of fracture orientations and shear senses in gouge-filled fractures therefore indicates complex internal deformation of Alpine Fault thrust sheets at shallow depths 
(a)

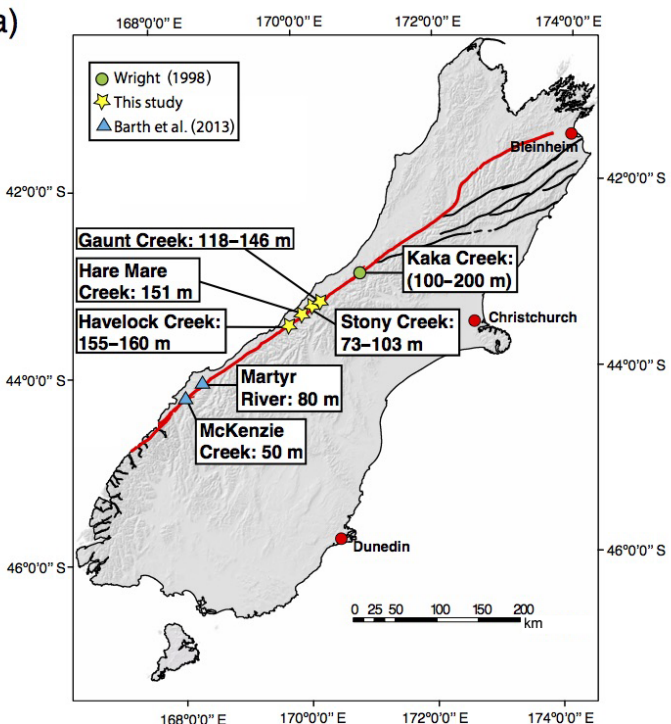

(b)

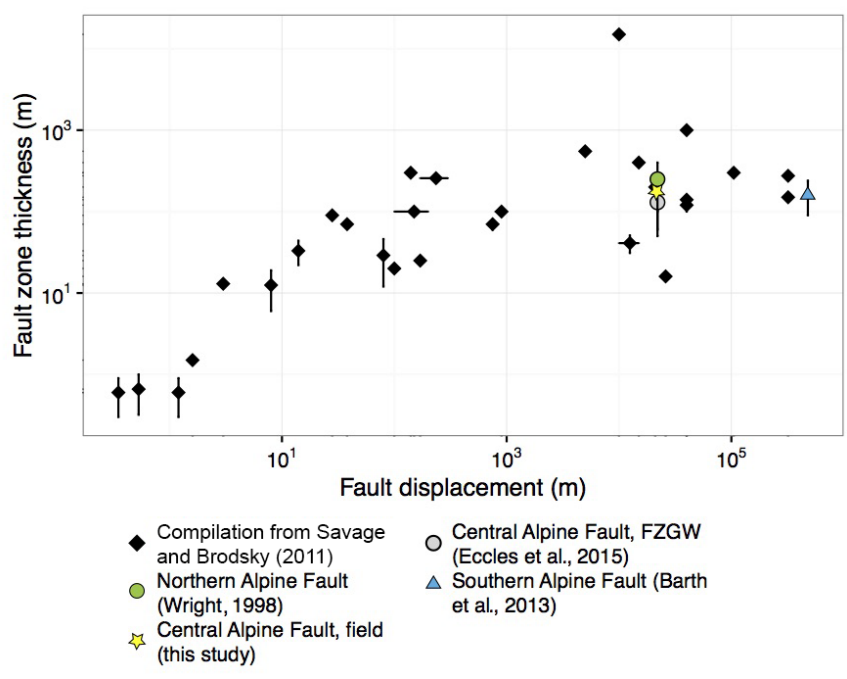

Figure 13. (a) Compilation of estimates of the inner damage zone width on the Pacific Plate side of the Alpine Fault (red line) from four creek sections in this study (Gaunt Creek, Stony Creek, Hare Mare Creek, and Havelock Creek). This is combined with other along-strike estimates of damage zone thickness for the Pacific Plate side of the Alpine Fault: McKenzie Creek and Martyr River (Barth et al., 2013) and Kaka Creek (Wright, 1998). (b) Log-log plot of fault zone thickness as a function of fault displacement previously presented in Savage and Brodsky (2011), combined with estimates made for the Alpine Fault assuming footwall damage is no more extensive than in the hanging wall. Displacement for the Alpine Fault is $480 \mathrm{~km}$ (Norris and Cooper, 2007; Wellman, 1953). However, convergence along the Alpine Fault's central section requires that it erodes its own fault rocks so these points are plotted to reflect only the brittle displacement the rocks themselves have accommodated as they are exhumed through the seismogenic zone $(22 \mathrm{~km}$, Barth et al., 2012). Error bars reflect uncertainty in constraining fault zone width (for example, footwall damage is largely unknown), not necessarily variability in fault zone thickness.

$(<500 \mathrm{~m})$, as they facilitate transpressional motion under the influence of kilometre-scale along-strike variations in stress induced by the topography (Norris and Cooper, 1995; Upton et al., 2017).

Fractures may have also formed due to dynamic offfault stresses (Ma, 2009; Rice et al., 2005) during $M_{\mathrm{W}}>7.5$ Alpine Fault earthquake ruptures (Sutherland et al., 2007). The relatively thin seismogenic crust in the Alpine Fault's hanging wall $(10 \pm 2 \mathrm{~km}$, Boese et al., 2012) will limit the generation of dynamic co-seismic damage to within $\sim 100$ $200 \mathrm{~m}$ of the fault (Ampuero and Mao, 2017). To the first order, this is comparable to the width of the inner damage zone reported here.

\subsection{Comparison to geophysical data}

A $60-200 \mathrm{~m}$ wide low-velocity zone (LVZ) that extends to depths of $\sim 8 \mathrm{~km}$ has been documented around the Alpine Fault from the detection and character of fault zone guided waves (FZGWs; Eccles et al., 2015). FZGWs are commonly regarded as an in situ indicator of fault damage zone width (Ben-Zion and Sammis, 2003; Eberhart-Phillips et al., 1995; Ellsworth and Malin, 2011; Li et al., 2014). Given the comparable widths of the Alpine Fault LVZ (60-200 m) and the inner damage zone described here $(100-160 \mathrm{~m})$, we speculate that the inner damage zone may trap FZGWs in the
Alpine Fault hanging wall. If this is true, it implies that the inner damage zone extends to depths of $\sim 8 \mathrm{~km}$, consistent with the relatively high-temperature $\left(<400^{\circ} \mathrm{C}\right)$ mineralising phases (calcite and chlorite) present in the gouge-filled fractures (Williams et al., 2017a).

Though the boundary between the mylonites and ultramylonites is also $\sim 100 \mathrm{~m}$ from the Alpine Fault (Norris and Cooper, 2003; Toy et al., 2008), these two units have roughly similar seismic velocities (Adam et al., 2016; Allen et al., 2017; Christensen and Okaya, 2007) and so are unlikely to channel FZGWs. We also note that since FZGWs are an indicator of total fault zone width, our interpretation implies that most of the Alpine Fault's LVZ is located in its hanging wall. Western province basement rocks to the west of the Alpine Fault are rarely exposed (Lund Snee et al., 2014; Norris and Cooper, 2007), and so it remains unknown if its footwall damage zone is indeed relatively narrow.

That the FZGWs are not being channelled by the margins of the $\sim 2 \mathrm{~km}$ wide outer damage zone leads us to conclude that this is a near-surface feature only (i.e. fractures are not kept open at depth by pressurised fluids). If correct, this model of the Alpine Fault's hanging-wall structure conforms to the expectations of fault zone flower structure models, which predict a narrow inner damage zone that extends through the seismogenic crust, surrounded by a wider 
zone of fractures at shallow depths at low confining pressures ( $\sim 3$ km, Fig. 12; e.g. Finzi et al., 2009; Sylvester, 1988).

\section{Conclusions}

Fracture orientations and densities in the foliated hanging wall of the Alpine Fault's central section were quantified in drill core from the DFDP-1, field transects in four creek sections, and drill core recovered from the Amethyst Hydro Project. At distances greater than approximately $160 \mathrm{~m}$ from the Alpine Fault PSZs, open and foliation-parallel fractures dominate. These are interpreted to form at low confining pressures in mechanically anisotropic schist and mylonites. At distances less than $\sim 160 \mathrm{~m}$ from the PSZs, gouge-filled fractures with a wide range of orientations predominate. Fracture density and orientation are locally influenced by changes in host rock lithology, but overall fracture density is approximately constant at distances of up to $\sim 500 \mathrm{~m}$ from the PSZs (Fig. 12).

Following Townend et al. (2017), we interpret that the $\sim 2 \mathrm{~km}$ wide zone of open foliation-parallel fractures within the hanging wall represents an outer damage zone that forms at low confining pressures and relatively shallow depths. Conversely, the $160 \mathrm{~m}$ wide zone of gouge-filled fractures represents an inner damage zone. The width of this zone is similar to estimates for the LVZ around the Alpine Fault made by fault zone guided waves. We therefore interpret that the inner damage zone is the geological manifestation of the LVZ, which, if true, implies that the inner damage zone also extends to depths of $\sim 8 \mathrm{~km}$. Overall, our interpretations are compatible with a flower structure model for damage in the Alpine Fault's hanging wall, with a relatively narrow zone of damage extending towards the base of the seismogenic crust, which broadens upwards towards the surface.
Code availability. The code to generate "unrolled" circumferential CT images is available from the GFZ data service (https://doi.org/ 10.5880/ICDP.5052.005, last access: 18 April 2018).

Data availability. In the Supplement, we include detailed field maps and cross sections (Fig. S1), photos of outcrops used for quantifying fracture density (Fig. S2), a cross section through the Amethyst Tunnel and location of boreholes (Fig. S3), and an example of AHP CT scans (Fig. S4). The following tables are also provided: a list of rotations applied to DFDP-1B core (Table S1), a summary of field transects including coordinates of the field-measuring stations (Table S2), and estimates of the distance of field-measuring stations from the Alpine Fault for different fault dips (Table S3). Lithological distribution and Alpine Fault location are as per the University of Otago fault zone mapping program, which is available at http://www.otago.ac.nz/geology/ research/structural-geology/alpine-fault/af-maps.html (last access: 18 April 2018). DFDP-1 and AHP CT scan "core logs" and CTBHTV image comparison are available on the GFZ data service (https://doi.org/10.5880/ICDP.5052.004, last access: 18 April 2018). 


\section{Appendix A: DFDP-1B core rotation methodology}

The technique employed to reorient core DFDP-1 here is similar to that described in Jarrard et al. (2001), Paulsen et al. (2002), and Shigematsu et al. (2014); however, instead of comparing DFDP-1 BHTV data to DMT CoreScan system ${ }^{\circledR}$ unrolled core scans, we compare BHTV images to "unrolled" CT core images. The acquisition and interpretation of the DFDP-1 BHTV logs have been previously described by Townend et al. (2013) and McNamara (2015). DFDP-1 CT scans consist of a stack of core-axial perpendicular image slices with a pixel size of $0.244 \mathrm{~mm}$ and a spacing of $1 \mathrm{~mm}$. The CT stack for each core section was loaded into Fiji (http://fiji.sc/Fiji, last access: 18 April 2018) and a circle was manually defined around the irregular boundary of drill core in a core axial-perpendicular image slice using the code available at Mills and Williams (2017). This circle was then used to define the path of the image in all other slices. Generation of the unrolled images accounts for the fact that the spacing between individual CT slices $(1 \mathrm{~mm}$, i.e. the core-axial parallel pixel size) is greater than the pixel size within the slices $(0.244 \mathrm{~mm})$. Drill core outer surface images and BHTV images are reflections of each other. Therefore, the drill core images were reflected about the borehole axis so that the two images are directly comparable. This technique has benefits over methods using the DMT CoreScan system ${ }^{\circledR}$, since drill core does not have to be physically rotated and so can be used without the risk of damaging fragile core sections.

Unrolled CT images were imported into the composite log viewing software WellCAD ${ }^{\circledR}$ (https://www.alt.lu/software. htm, last access: 18 April 2018) along with the BHTV images, where they are placed side by side to allow matching of structures (Fig. 4; see also Williams et al., 2017b). When correlating the two datasets, it was first necessary to account for possible depth shifts between recorded drill-core depths and BHTV imagery due to factors such as stretching of the logging cable and intervals from which no drill core was recovered (Haggas et al., 2001; Jarrard et al., 2001). In this study, a depth shift of no more than $\pm 30 \mathrm{~cm}$ was allowed.

The orientation of fractures in the DFDP-1 CT images had previously been measured within a local core reference frame (see Fig. 4 in Williams et al., 2016). Since the DFDP-1 boreholes were vertical, corrections to reorient the drill core back into a geographic reference frame required only a single rotation about the core axis to correct for the dip direction. When correlating structures, errors may be introduced by (1) the internal BHTV magnetometer $\left( \pm 2^{\circ}\right)$, (2) the manual picking of sinusoidal curves on BHTV and unrolled CT images that can be $\pm 10^{\circ}$ for shallowly dipping $\left(<30^{\circ}\right)$ structures (Jarrard et al., 2001), and (3) the fact that the DFDP-1B BHTV data imaged the open borehole, which has a larger diameter $(127 \mathrm{~mm})$ than the drill core $(85 \mathrm{~mm})$. To mitigate against the cumulative effect of these errors, Jarrard et al. (2001) stitched unrolled images of many different core sections to- gether that spanned intervals of 5-30 m, prior to the matching with BHTV imagery. This meant that only a single rotation was necessary for all core sections across the entire stitched interval, which could be based on identifying $\sim 20$ 30 matching structures between the BHTV and unrolled core images.

In DFDP-1, it was not possible to stitch unrolled CT images of core section together as no prominent reference markers across different sections were identified. Consequently, each $<1 \mathrm{~m}$ long core section had to be reoriented individually, within which we never identified more than three matching structures. Therefore, compared to the methodology described by Jarrard et al. (2001), the degree of confidence on the applied reorientation was strongly dependent on the quality of individual matches for each core section and the range of rotations that they indicated. We recorded this qualitatively for each core section using the scheme outlined below.

- High degree of confidence: images matched with one very prominent structure (e.g. Fig. 4d) or with two or more structures whose ranges of suggested rotations are within $10^{\circ}$ of each other (Fig. $4 \mathrm{~b}$ and c).

- Moderate degree of confidence: images matched with one prominent feature, two features that indicate rotations that range $10-19^{\circ}$ (e.g. Fig. $4 \mathrm{a}$ ), or three features whose ranges of suggested rotations are within $20-30^{\circ}$ of each other.

- Low degree of confidence: images matched with one feature or two features whose ranges of suggested rotations are within $20-30^{\circ}$ of each other.

In this scheme, a core reorientation is deemed unreliable if the range of rotations suggested by different structures is $\geq 30^{\circ}$, i.e. equivalent to the cumulative effect of possible errors listed above. For those core sections where more than one matching structure was identified, the rotation that was applied was derived from the average of that required for each match. If one of the matched structures was more prominent, then the applied rotation was biased towards that structure. 


\section{Appendix B: DFDP-1B core rotation validity}

Based on the criteria presented in Appendix A, of the 40 core sections from DFDP-1B in which there was suitable quality of unrolled CT and BHTV images to attempt reorientation (Fig. 3), 31 were reoriented (Table S1). Prior to reorientation, fractures in these sections exhibit no clustering (Fig. B1a); however, a weak one does develop after reorientation (Fig. 5a). Since fractures in nature typically exhibit non-random orientations, this is evidence that the reorientation of the CT scans was successful (Kulander et al., 1990; Paulsen et al., 2002). In addition, fractures within some individual core sections (Fig. B1b) and fractures rotated based on a high degree of confidence (Fig. B1c) contain a wide range of orientations.
The recognition of fractures in unrolled $\mathrm{CT}$ images that are not observed in BHTV can be readily explained by the higher resolution of the CT images. However, structures are also observed in the BHTV logs but not interpreted as fractures in the CT images (Fig. 4). This may represent noise in the BHTV images, or in the case of foliation-parallel structures, the ultramylonitic foliation itself since it can be difficult to differentiate these structures. The subordinate north-dipping set of fractures in the BHTV images (Fig. 5b) is not recognised in the orientations gathered from CT images (Fig. 5a). A similar north-dipping fracture set was also recognised in DFDP-2B BHTV images (Massiot, 2017), and their causation and relevance are the focus of ongoing work.
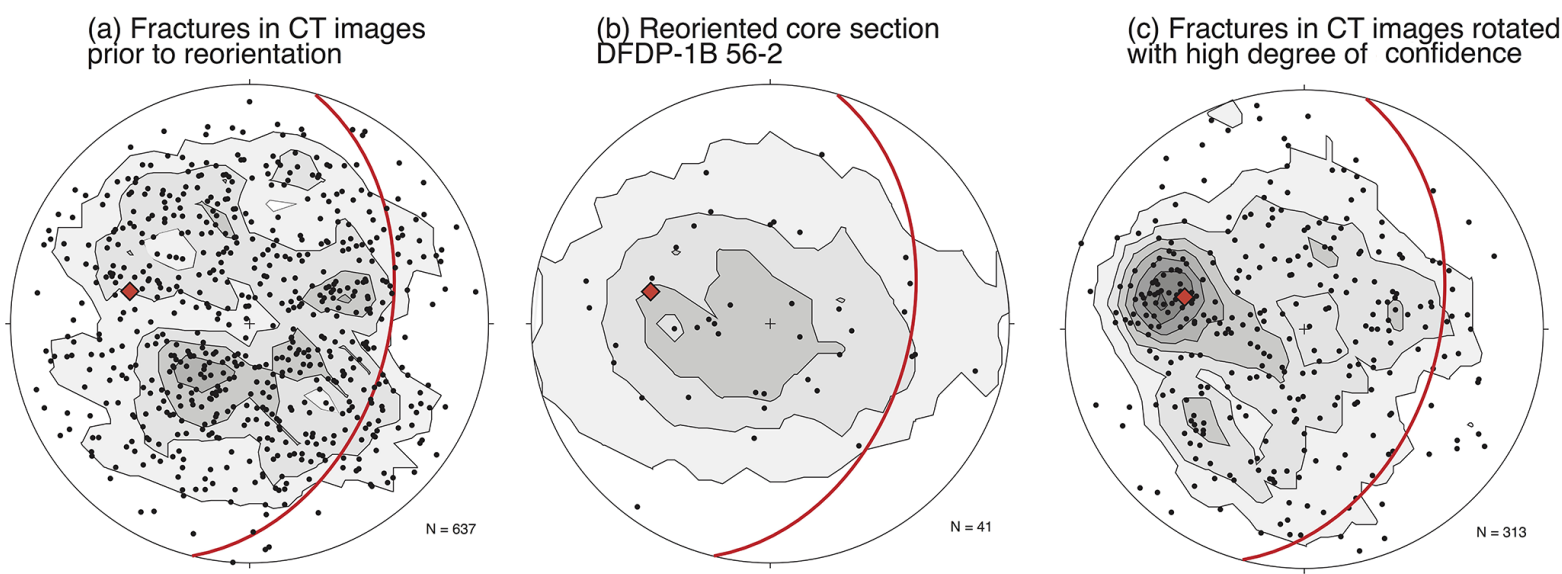

Figure B1. Stereoplots to tests the confidence in reorientations applied to rotate DFDP-1 CT scan fracture orientations into geographic coordinates. Red great circle and diamond in each plot represent the plane and pole to the Alpine Fault orientation measured in DFDP1B. Plotted with Kamb contours with intervals of 2 standard deviations. (a) Orientation of fractures shown in Fig. 5a before rotation, (b) orientation of reoriented fractures within a single core section (DFDP-1B 56-2), and (c) orientation of fractures in CT images from core sections that were oriented with a high degree of confidence with BHTV images. 


\section{The Supplement related to this article is available online at https://doi.org/10.5194/se-9-469-2018-supplement.}

Competing interests. The authors declare that they have no conflict of interest.

Acknowledgements. DFDP-1 was funded by GNS Science; Victoria University of Wellington; the University of Otago; the University of Auckland; the University of Canterbury; Deutsche Forschungsgemeinschaft and the University of Bremen; Natural Environment Research Council grants NE/J024449/1, NE/ G524160/1 and NE/H012486/1 and the University of Liverpool; and the Marsden Fund of the Royal Society of New Zealand. The International Continental Scientific Drilling Program, ICDP (www.icdp-online.org) provided extensive support. Jack N. Williams was supported by a University of Otago Doctoral Scholarship. We thank Matthew Parris at the Oncology Department at Dunedin Hospital, and Darren Tod at the Southern Cross Hospital, Wellington, for support in collecting CT scans of DFDP-1 Amethyst Hydro Project drill core, respectively. Katrina Sauer, Ben Melosh, and Astrid Vetrhus provided field assistance. Comments by Tim Little and Tom Blenkinsop, and by two anonymous reviewers on an earlier version of the manuscript, improved this paper.

Edited by: Bernhard Grasemann

Reviewed by: Tim Little and Thomas Blenkinsop

\section{References}

Adam, L., Toy, V., and Boulton, C.: Mylonites as shales? Experimental observations of P-wave anisotropy dependence on mineralogy, layering and scale, in: SEG Technical Program Expanded Abstracts 2016, 3169-3173, Society of Exploration Geophysicists, 2016.

Allen, M. J., Tatham, D., Faulkner, D. R., Mariani, E., and Boulton, C.: Permeability and seismic velocity and their anisotropy across the Alpine Fault, New Zealand: An insight from laboratory measurements on core from the Deep Fault Drilling Project phase 1 (DFDP-1), J. Geophys.-Res.-Sol. Ea., 122, 6160-6179, https://doi.org/10.1002/2017JB014355, 2017.

Ampuero, J. P. and Mao, X.: Upper limit on damage zone thickness controlled by seismogenic depth, Fault Zo. Dyn. Process. Evol. Fault Prop. Dur. Seism. Rupture, 227, 243-253, 2017.

Andrews, D. J.: Rupture dynamics with energy loss outside the slip zone, J. Geophys.-Res.-Sol. Ea., 110, 1-14, https://doi.org/10.1029/2004JB003191, 2005.

Barth, N. C., Toy, V. G., Langridge, R. M., and Norris, R. J.: Scale dependence of oblique plate-boundary partitioning: New insights from LiDAR, central Alpine fault, New Zealand, Lithosphere, 4, 435-448, https://doi.org/10.1130/L201.1, 2012.

Barth, N. C., Boulton, C., Carpenter, B. M., Batt, G. E., and Toy, V. G.: Slip localization on the southern Alpine Fault New Zealand, Tectonics, 32, 620-640, https://doi.org/10.1002/tect.20041, 2013.
Ben-Zion, Y. and Sammis, C. G.: Characterization of Fault Zones, Pure Appl. Geophys., 160, 677-715, https://doi.org/10.1007/PL00012554, 2003.

Berg, S. S. and Skar, T.: Controls on damage zone asymmetry of a normal fault zone: Outcrop analyses of a segment of the Moab fault, SE Utah, J. Struct. Geol., 27, 1803-1822, https://doi.org/10.1016/j.jsg.2005.04.012, 2005.

Bistacchi, A., Massironi, M., and Menegon, L.: Three-dimensional characterization of a crustal-scale fault zone: The Pusteria and Sprechenstein fault system (Eastern Alps), J. Struct. Geol., 32, 2022-2041, https://doi.org/10.1016/j.jsg.2010.06.003, 2010.

Bistacchi, A., Massironi, M., Menegon, L., Bolognesi, F., and Donghi, V.: On the nucleation of non-Andersonian faults along phyllosilicate-rich mylonite belts, Geol. Soc. London, Spec. Publ., 367, 185-199, https://doi.org/10.1144/sp367.13, 2012.

Boese, C. M. M., Townend, J., Smith, E., and Stern, T.: Microseismicity and stress in the vicinity of the Alpine Fault, central Southern Alps, New Zealand, J. Geophys.-Res.-Sol. Ea., 117, B02302, https://doi.org/10.1029/2011JB008460, 2012.

Boulton, C., Yao, L., Faulkner, D. R., Townend, J., Toy, V. G., Sutherland, R., Ma, S., and Shimamoto, T.: Highvelocity frictional properties of Alpine Fault rocks: Mechanical data, microstructural analysis, and implications for rupture propagation, J. Struct. Geol., 97, 71-92, https://doi.org/10.1016/j.jsg.2017.02.003, 2017.

Boulton, C. J., Carpenter, B. M., Toy, V., and Marone, C.: Physical properties of surface outcrop cataclastic fault rocks, Alpine Fault, New Zealand, Geochem., Geophy. Geosy., 13, Q01018, https://doi.org/10.1029/2011GC003872, 2012.

Caine, J. S., Evans, J. P., and Forster, C. B.: Fault zone architecture and permeability structure, Geology, 24, 1025-1028, 1996.

Chamberlain, C. J., Boese, C. M., and Townend, J.: Crosscorrelation-based detection and characterisation of microseismicity adjacent to the locked, late-interseismic Alpine Fault, South Westland, New Zealand, Earth Planet. Sci. Lett., 457, 6372, https://doi.org/10.1016/j.epsl.2016.09.061, 2017.

Chester, F. M. and Chester, J. S.: Stress and deformation along wavy frictional faults, J. Geophys. Res., 105, 23421, https://doi.org/10.1029/2000JB900241, 2000.

Chester, F. M. and Logan, J. M.: Implications for mechanical properties of brittle faults from observations of the Punchbowl fault zone, California, Pure Appl. Geophys. PAGEOPH, 124, 79-106, https://doi.org/10.1007/BF00875720, 1986.

Chester, F. M., Evans, J. P., and Biegel, R. L.: Internal structure and weakening mechanisms of the San Andreas Fault, J. Geophys. Res., 98, 771, https://doi.org/10.1029/92JB01866, 1993.

Chester, J. S. and Fletcher, R. C.: Stress distribution and failure in anisotropic rock near a bend on a weak fault, J. Geophys. Res.Earth, 102, 693-708, https://doi.org/10.1029/96JB02791, 1997.

Choi, J. H., Edwards, P., Ko, K., and Kim, Y. S.: Definition and classification of fault damage zones: A review and a new methodological approach, Earth-Science Rev., 152, 70-87, https://doi.org/10.1016/j.earscirev.2015.11.006, 2016.

Christensen, N. I. and Okaya, D. A.: Compressional and shear wave velocities in South Island, New Zealand rocks and their application to the interpretation of seismological models of the New Zealand crust, A Cont. Plate Bound. Tectonics South Island, New Zeal., 123-155, 2007. 
Columbus, J., Sirguey, P., and Tenzer, R.: A free, fully assessed 15m DEM for New Zealand, Surv. Q., 66, 16-19, 2011.

Cooper, A. F. and Norris, R. J.: Anatomy, structural evolution, and slip rate of a plate-boundary thrust: the Alpine Fault at Gaunt Creek, Westland, New Zealand, Geol. Soc. Am. Bull., 106, 627-633, https://doi.org/10.1130/00167606(1994)106<0627:ASEASR>2.3.CO;2, 1994.

Cooper, A. F. and Norris, R. J.: Inverted metamorphic sequences in Alpine fault mylonites produced by oblique shear within a plate boundary fault zone, Geology, New Zealand, 39, 10231026, 2011.

Cowie, P. A. and Scholz, C. H.: Physical Explanation for the Displacement Length Relationship of Faults Using a Post-Yield Fracture-Mechanics Model, J. Struct. Geol., 14, 1133-1148, https://doi.org/10.1016/0191-8141(92)90065-5, 1992.

Cox, S., and Barrel, D. J. A.: Geology of the Aoraki area, Institute of Geological and Nuclear Sciences, 1:250 000 Geological Map, Lower Hutt, New Zealand (GNS Science), 71, 2007.

Cox, S. C., Menzies, C. D., Sutherland, R., Denys, P. H., Chamberlain, C., and Teagle, D. A. H.: Changes in hot spring temperature and hydrogeology of the Alpine Fault hanging wall, New Zealand, induced by distal South Island earthsquakes, Geofluids, 15, 216-239, 2015.

DeMets, C., Gordon, R. G., Argus, D. F., and Stein, S.: Effect of recent revisions to the geomagnetic reversal time scale on estimate of current plate motions, Geophys. Res. Lett., 21, 2191-2194, https://doi.org/10.1029/94GL02118, 1994.

Donath, F. A.: Experimental study of shear failure in anisotropic rocks, Geol. Soc. Am. Bull., 72, 985-989, https://doi.org/10.1130/00167606(1961)72[985:ESOSFI]2.0.CO;2, 1961.

Eberhart-Phillips, D., Stanley, W. D., Rodriguez, B. D., and Lutter, W. J.: Surface seismic and electrical methods to detect fluids related to faulting, J. Geophys. Res., 100, 12919-12936, https://doi.org/10.1029/94JB03256, 1995.

Eberhart-Phillips, D.: Examination of seismicity in the central Alpine fault region, South Island, New Zealand, New Zeal. J. Geol. Geophys., 38, 571-578, 1995.

Eccles, J. D., Gulley, A. K., Malin, P. E., Boese, C. M., Townend, J., and Sutherland, R.: Fault Zone Guided Wave generation on the locked, late interseismic Alpine Fault, New Zealand, Geophys. Res. Lett., 42, 5736-5743, https://doi.org/10.1002/2015GL064208, 2015.

Ellsworth, W. L. and Malin, P. E.: Deep rock damage in the San Andreas Fault revealed by P- and S-type fault-zone-guided waves, in: Geol. Earthq. Source A Vol. Honor Rick Sibson, edited by: Fagereng, A., Toy, V. G., and Rowland, J., Geol. Soc. London, Spec. Publ., 359, 39-53, https://doi.org/10.1144/SP359.3, 2011.

Engelder, T.: Loading paths to joint propagation during a tectonic cycle: an example from the Appalachian Plateau, U.S.A., J. Struct. Geol., 7, 459-476, https://doi.org/10.1016/01918141(85)90049-5, 1985

Faulkner, D. R., Jackson, C. A. L., Lunn, R. J., Schlische, R. W., Shipton, Z. K., Wibberley, C. A. J., and Withjack, M. O.: A review of recent developments concerning the structure, mechanics and fluid flow properties of fault zones, J. Struct. Geol., 32, 1557-1575, https://doi.org/10.1016/j.jsg.2010.06.009, 2010.

Faulkner, D. R., Mitchell, T. M., Jensen, E., and Cembrano, J.: Scaling of fault damage zones with displacement and the implica- tions for fault growth processes, J. Geophys.-Res.-Sol. Ea., 116 , B05403, https://doi.org/10.1029/2010JB007788, 2011.

Finzi, Y., Hearn, E. H., Ben-Zion, Y., and Lyakhovsky, V.: Structural properties and deformation patterns of evolving strike-slip faults: Numerical simulations incorporating damage rheology, Pure Appl. Geophys., 166, 1537-1573, https://doi.org/10.1007/s00024-009-0522-1, 2009.

Haggas, S., Brewer, T. S., Harvey, P. K., and Iturrino, G. I.: Relocating and orientating cores by the integration of electrical and optical images, J. Geol. Soc. London, 158, 615-623, https://doi.org/10.1144/jgs.158.4.615, 2001.

Ikari, M. J., Carpenter, B. M., Kopf, A. J., and Marone, C.: Frictional strength, rate-dependence, and healing in DFDP-1 borehole samples from the Alpine Fault, New Zealand, Tectonophysics, 630, 1-8, https://doi.org/10.1016/j.tecto.2014.05.005, 2014.

Jarrard, R. D., Paulsen, T. S., and Wilson, T. J.: Orientation of CRP3 core, Victoria Land Basin, Antarctica, Terra Antarct., 8, 161166, 2001.

Kim, Y. S. and Sanderson, D. J.: Fault propagation, displacement and damage zones, Struct. Geol. New Res., 1, 99-117, 2008.

Kim, Y. S., Peacock, D. C. P., and Sanderson, D. J.: Fault damage zones, J. Struct. Geol., 26, 503-517, https://doi.org/10.1016/j.jsg.2003.08.002, 2004.

Kulander, B. R., Dean, S. L., and Ward, B. J.: Fracture core analysis: interpretation, logging and use of natural and induced fractures in core, vol. 8, American Association of Petroleum Geologists, 88 pp., 1990.

Langridge, R. M., Ries, W. F., Farrier, T., Barth, N. C., Khajavi, N., and De Pascale, G. P.: Developing sub 5$m$ LiDAR DEMs for forested sections of the Alpine and Hope faults, South Island, New Zealand: Implications for structural interpretations, J. Struct. Geol., 64, 53-66, https://doi.org/10.1016/j.jsg.2013.11.007, 2014.

Lees, J. M.: RFOC: Graphics for spherical distributions and earthquake focal mechanisms, $\mathrm{R}$ package version 3.3-3, available at: http://CRAN.R-project.org/package=RFOC (last access: 18 April 2018), R Packag. version, 3, 2014.

Li, Y. G., De Pascale, G. P., Quigley, M. C., and Gravley, D. M.: Fault damage zones of the M7.1 Darfield and M6.3 Christchurch earthquakes characterized by fault-zone trapped waves, Tectonophysics, 618, 79-101, https://doi.org/10.1016/j.tecto.2014.01.029, 2014.

Little, T. A., Cox, S., Vry, J. K., and Batt, G.: Variations in exhumation level and uplift rate along the obliqu-slip Alpine fault, central Southern Alps, New Zealand, Geol. Soc. Am. Bull., 117, 707-723, https://doi.org/10.1130/B25500.1, 2005.

Lund Snee, J. E., Toy, V. G., and Gessner, K.: Significance of brittle deformation in the footwall of the Alpine Fault, New Zealand: Smithy Creek Fault zone, J. Struct. Geol., 64, 79-98, https://doi.org/10.1016/j.jsg.2013.06.002, 2014.

Ma, S.: Distinct asymmetry in rupture-induced inelastic strain across dipping faults: An off-fault yielding model, Geophys. Res Lett., 36, L20317, https://doi.org/10.1029/2009GL040666, 2009.

Manning, C. E. and Ingebritsen, S. E.: Permeability of the continental crust: Implications of geothermal data and metamorphic systems, Rev. Geophys., 37, 127-150, https://doi.org/10.1029/1998RG900002, 1999. 
Massiot, C.: Fracture system characterisation and implications for fluid flow in volcanic and metamorphic rocks, available at: http: //hdl.handle.net/10063/6194 (last access: 18 April 2018), 1-191, 2017.

Massiot, C., Mcnamara, D. D., and Lewis, B.: Geothermics Processing and analysis of high temperature geothermal acoustic borehole image logs in the Taupo Volcanic Zone, New Zealand, Geothermics, 53, 190-201, https://doi.org/10.1016/j.geothermics.2014.05.010, 2015.

Massironi, M., Bistacchi, A., and Menegon, L.: Misoriented faults in exhumed metamorphic complexes: Rule or exception?, Earth Planet. Sci. Lett., 307, 233-239, https://doi.org/10.1016/j.epsl.2011.04.041, 2011.

Mauldon, M., Dunne, W. M., and Rohrbaugh, M. B.: Circular scanlines and circular windows: New tools for characterizing the geometry of fracture traces, J. Struct. Geol., 23, 247-258, https://doi.org/10.1016/S0191-8141(00)00094-8, 2001.

McCahon, I.: Amethyst Hydro Scheme 2006 Drilling Investigation Summary Report, Prepared by Geotech Consulting Company Limited for Westpower Limited, GNS Science library, No. 2745, 41 pp., 2006.

McNamara, D.: Exploring New Zealand's subsurface using borehole images, in Presented at the 2015 New Zealand Geosciences Conference, Wellington, 25-27th November, 2015.

Mills, S. and Williams, J. N.: Generating circumferential images of tomographic drill-core scans, GFZ Data Serv., available at: https://doi.org/10.5880/ICDP.5052.005 (last access: 18 April 2018), 2017.

Misra, S., Ellis, S., and Mandal, N.: Fault damage zones in mechanically layered rocks: The effects of planar anisotropy, J. Geophys. Res., 120, 5432-5452, https://doi.org/10.1002/2014JB011780, 2015.

Mitchell, T. M. and Faulkner, D. R.: The nature and origin of off-fault damage surrounding strike-slip fault zones with a wide range of displacements: A field study from the Atacama fault system, northern Chile, J. Struct. Geol., 31, 802-816, https://doi.org/10.1016/j.jsg.2009.05.002, 2009.

Mitchell, T. M. and Toy, V. G.: Photograph of the month, J. Struct. Geol., 64, iii, https://doi.org/10.1016/S0191-8141(14)00094-7, 2014.

Muir-Wood, R. and King, G. C. P.: Hydrological signatures of earthquake strain, J. Geophys. Res., 98, 22035, https://doi.org/10.1029/93JB02219, 1993.

Nasseri, M. H. B., Rao, K. S., and Ramamurthy, T.: Anisotropic strength and deformation behavior of Himalayan schists, Int. J. Rock Mech. Min. Sci., 40, 3-23, https://doi.org/10.1016/S13651609(02)00103-X, 2003.

Norris, R. J. and Cooper, A. F.: Origin of small-scale segmentation and transpressional thrusting along the Alpine Fault, New Zealand, Geol. Soc. Am. Bull., 107, 231-240, https://doi.org/10.1130/00167606(1995)107<0231:OOSSSA>2.3.CO;2, 1995.

Norris, R. J. and Cooper, A. F.: Erosional control on the structural evolution of a transpressional thrust complex on the Alpine fault, New Zealand, J. Struct. Geol., 19, 1323-1342, https://doi.org/10.1016/S0191-8141(97)00036-9, 1997.

Norris, R. J. and Cooper, A. F.: Late Quaternary slip rates and slippartitioning on the Alpine Fault, New Zealand, J. Struct. Geol., 23, 507-520, 2001.
Norris, R. J. and Cooper, A. F.: Very high strains recorded in mylonites along the Alpine Fault, New Zealand: implications for the deep structure of plate boundary faults, J. Struct. Geol., 25, 2141-2157, 2003.

Norris, R. J. and Cooper, A. F.: The Alpine Fault, New Zealand: Surface Geology and Field Relationships, in: A Continental Plate Boundary: Tectonics at South Island, New Zealand, edited by: Okaya, D., Stern, T. A., and Davey, F., 157-175, American Geophysical Union, https://doi.org/10.1029/175GM09, 2007.

Norris, R. J. and Toy, V. G.: Continental transforms: A view from the Alpine Fault, J. Struct. Geol., 64, 3-31, https://doi.org/10.1016/j.jsg.2014.03.003, 2014.

O'Brien, G. A., Cox, S. C., and Townend, J.: Spatially and temporally systematic hydrologic changes within large geoengineered landslides, Cromwell Gorge, New Zealand, induced by multiple regional earthquakes, J. Geophys.-Res.-Sol. Ea., 121, 87508773, 2016.

Paterson, M. S. and Wong, T. F.: Experimental rock deformation The brittle field, Springer-Verlag Berlin Heidelberg, 2005.

Paulsen, T. S., Jarrard, R. D., and Wilson, T. J.: A simple method for orienting drill core by correlating features in whole-core scans and oriented borehole-wall imagery, J. Struct. Geol., 24, 12331238, https://doi.org/10.1016/S0191-8141(01)00133-X, 2002.

Peacock, D. C. P. and Sanderson, D. J.: Effects of layering and anisotropy on fault geometry, J. Geol. Soc. London, 149, 793802, https://doi.org/10.1144/gsjgs.149.5.0793, 1992.

Price, N. J.: Mechanics of jointing in rocks, Geol. Mag., 96, 149167, https://doi.org/10.1017/S0016756800060040, 1959.

Priest, S.: Discontinuity Analysis for Rock Engineering, Springer Science \& Business Media, 1993.

Rattenbury, M. and Isaac, M.: The QMAP 1:250000 Geological Map of New Zealand project, New Zeal. J. Geol. Geophys., 8306, https://doi.org/10.1080/00288306.2012.725417, 55, 393405, 2012.

Reed, J. J.: Mylonites, cataclasites, and associated rocks along the Alpine fault, South Island, New Zealand, New Zeal. J. Geol. Geophys., 7, 645-684, https://doi.org/10.1080/00288306.1964.10428124, 1964.

Rice, J. R., Sammis, C. G., and Parsons, R.: Off-fault secondary failure induced by a dynamic slip pulse, Bull. Seismol. Soc. Am., 95, 109-134, https://doi.org/10.1785/0120030166, 2005.

Savage, E.: Investigating Rock Mass Conditions and Implications for Tunnelling and Construction of the Amethyst Hydro Project, Harihari, University of Canterbury, 2013.

Savage, H. M. and Brodsky, E. E.: Collateral damage: Evolution with displacement of fracture distribution and secondary fault strands in fault damage zones, J. Geophys.-Res.-Sol. Ea., 116, B03405, https://doi.org/10.1029/2010JB007665, 2011.

Savage, H. M., Keranen, K. M., Schaff, D., and Dieck, C.: Possible Precursory Signals in Damage Zone Foreshocks, Geophys. Res. Lett., 4, 5411-5417, 2017.

Schulz, S. E. and Evans, J. P.: Mesoscopic structure of the Punchbowl Fault, Southern California and the geologic and geophysical structure of active strike-slip faults, J. Struct. Geol., 22, 913930, https://doi.org/10.1016/S0191-8141(00)00019-5, 2000.

Shigematsu, N., Otsubo, M., Fujimoto, K., and Tanaka, N.: Orienting drill core using borehole-wall image correlation analysis, J. Struct. Geol., 67, 293-299, https://doi.org/10.1016/j.jsg.2014.01.016, 2014. 
Sibson, R. H.: Earthquake faulting as a structural process, J. Struct. Geol., 11, 1-14, https://doi.org/10.1016/0191-8141(89)90032-1, 1989.

Sibson, R. H., White, S. H., and Atkinson, B. K.: Structure and distribution of fault rocks in the Alpine Fault Zone, New Zealand, Geol. Soc. London, Spec. Publ., 9, 197-210, 1981.

Simpson, G. D. H., Cooper, A. F., and Norris, R. J.: Late Quaternary evolution of the Alpine Fault Zone at Paringa, South Westland, New Zealand, New Zeal. J. Geol. Geophys., 37, 49-58, https://doi.org/10.1080/00288306.1994.9514600, 1994.

Stanley, C. R. and Hooper, J. J.: POND: An Excel spreadsheet to obtain structural attitudes of planes from oriented drillcore, Comput. Geosci., 29, 531-537, https://doi.org/10.1016/S00983004(03)00033-5, 2003.

Stern, T., Okaya, D., Kleffmann, S., Scherwath, M., Henrys, S., and Davey, F.: Geophysical exploration and dynamics of the Alpine Fault Zone, A Cont. Plate Bound. Tectonics South Island, New Zeal. Geophys. Monogr. Ser., 175, 207-233, https://doi.org/10.1029/175GM11, 2007.

Sutherland, R., Eberhart-Phillips, D., Harris, R. A., Stern, T., Beavan, J., Ellis, S., Henrys, S., Cox, S., Norris, R. J., Berryman, K. R., Townend, J., Bannister, S., Pettinga, J., Leitner, B., Wallace, L., Little, T. A., Cooper, A. F., Yetton, M., and Stirling, M.: Do Great Earthquakes Occur on the Alpine Fault in Central South Island, New Zealand?, in: A Continental Plate Boundary: Tectonics at South Island, New Zealand, 175, edited by: Okaya, D., Stern, T., and Davey, F., 235-251, American Geophysical Union, https://doi.org/10.1029/175GM12, 2007.

Sutherland, R., Toy, V. G., Townend, J., Cox, S. C., Eccles, J. D., Faulkner, D. R., Prior, D. J., Norris, R. J., Mariani, E., Boulton, C., Carpenter, B. M., Menzies, C. D., Little, T. A., Hasting, M., De Pascale, G. P., Langridge, R. M., Scott, H. R., Reid Lindroos, Z., Fleming, B., and Kopf, J.: Drilling reveals fluid control on architecture and rupture of the Alpine fault, New Zealand, Geology, 40, 1143-1146, https://doi.org/10.1130/G33614.1, 2012.

Sutherland, R., Townend, J., Toy, V. G., Upton, P., Coussens, J., and DFDP2, S. T.: Extreme hydrothermal conditions at an active plate-bounding fault, Nature, 546, 137-140, https://doi.org/10.1038/nature22355, 2017.

Sylvester, A. G.: Strike-Slip Faults, Geol. Soc. Am. Bull., 100, 1666-1703, https://doi.org/10.1130/00167606(1988)100<1666:SSF>2.3.CO;2, 1988.

Templeton, E. L., Rice, J. R., Viesca, R. C., Templeton, E. L., and Rice, J. R.: Off-fault plasticity and earthquake rupture dynamics: 2. Effects of fluid saturation, J. Geophys.-Res.-Sol. Ea., 113, https://doi.org/10.1029/2007JB005530, 2008.

Terzaghi, R. D.: Sources of Error in Joint Surveys, Géotechnique, 15, 287-304, https://doi.org/10.1680/geot.1965.15.3.287, 1965.

Tippett, J. M. and Kamp, P. J. J.: Quantitative relationships between uplift and relief parameters for the Southern Alps, New Zealand, as determined by fission track analysis, Earth Surf. Process. Landforms, 20, 153-175, 1995.

Townend, J. and Zoback, M. D.: How faulting keeps the crust strong, Geology, 28, 399-402, https://doi.org/10.1130/00917613(2000)28<399:HFKTCS>2.0.CO;2, 2000.

Townend, J., Sutherland, R., Toy, V. G., Eccles, J. D., Boulton, C., Cox, S. C., and McNamara, D.: Late-interseismic state of a continental plate-bounding fault: Petrophysical results from DFDP-1 wireline logging and core analysis, Alpine
Fault, New Zealand, Geochem., Geophy. Geosy., 14, 3801-3820, https://doi.org/10.1002/ggge.20236, 2013.

Townend, J., Sutherland, R., Toy, V. G., Doan, M. L., Célérier, B., Massiot, C., Coussens, J., Jeppson, T., Janku-Capova, L., Remaud, L., Upton, P., Schmitt, D. R., Pezard, P., Williams, J., Allen, M. J., Baratin, L. M., Barth, N., Becroft, L., Boese, C. M., Boulton, C., Broderick, N., Carpenter, B., Chamberlain, C. J., Cooper, A., Coutts, A., Cox, S. C., Craw, L., Eccles, J. D., Faulkner, D., Grieve, J., Grochowski, J., Gulley, A., Hartog, A., Henry, G., Howarth, J., Jacobs, K., Kato, N., Keys, S., Kirilova, M., Kometani, Y., Langridge, R., Lin, W., Little, T., Lukacs, A., Mallyon, D., Mariani, E., Mathewson, L., Melosh, B., Menzies, C., Moore, J., Morales, L., Mori, H., Niemeijer, A., Nishikawa, O., Nitsch, O., Paris, J., Prior, D. J., Sauer, K., Savage, M. K., Schleicher, A., Shigematsu, N., Taylor-Offord, S., Teagle, D., Tobin, H., Valdez, R., Weaver, K., Wiersberg, T., and Zimmer, M.: Petrophysical, Geochemical, and Hydrological Evidence for Extensive Fracture-Mediated Fluid and Heat Transport in the Alpine Fault's Hanging-Wall Damage Zone, Geochem., Geophy. Geosy., 18, 4709-4732, https://doi.org/10.1002/2017GC007202, 2017.

Toy, V.: Rheology of the Alpine Fault mylonite zone: deformation processes at and below the base of the seismogenic zone in a major plate boundary structure, University of Otago, available at: http://hdl.handle.net/10523/4548 (last access: 18 April 2018), 2008.

Toy, V. G., Prior, D. J., and Norris, R. J.: Quartz fabrics in the Alpine Fault mylonites: Influence of pre-existing preferred orientations on fabric development during progressive uplift, J. Struct. Geol., 30, 602-621, https://doi.org/10.1016/j.jsg.2008.01.001, 2008.

Toy, V. G., Craw, D., Cooper, A. F., and Norris, R. J.: Thermal regime in the central Alpine Fault zone, New Zealand: Constraints from microstructures, biotite chemistry and fluid inclusion data, Tectonophysics, 485, 178-192, https://doi.org/10.1016/j.tecto.2009.12.013, 2010.

Toy, V. G., Boulton, C. J., Sutherland, R., Townend, J., Norris, R. J., Little, T. A., Prior, D. J., Mariani, E., Faulkner, D., Menzies, C. D., Scott, H., and Carpenter, B. M.: Fault rock lithologies and architecture of the central Alpine fault, New Zealand, revealed by DFDP-1 drilling, Lithosphere, 7, 155-173, https://doi.org/10.1130/1395.1, 2015.

Toy, V. G., Sutherland, R., Townend, J., Allen, M. J., Becroft, L., Boles, A., Boulton, C., Carpenter, B., Cooper, A., Cox, S. C., Daube, C., Faulkner, D. R., Halfpenny, A., Kato, N., Keys, S., Kirilova, M., Kometani, Y., Little, T., Mariani, E., Melosh, B., Menzies, C. D., Morales, L., Morgan, C., Mori, H., Niemeijer, A., Norris, R., Prior, D., Sauer, K., Schleicher, A. M., Shigematsu, N., Teagle, D. A. H., Tobin, H., Valdez, R., Williams, J., Yeo, S., Baratin, L. M., Barth, N., Benson, A., Boese, C., Célérier, B., Chamberlain, C. J., Conze, R., Coussens, J., Craw, L., Doan, M. L., Eccles, J., Grieve, J., Grochowski, J., Gulley, A., Howarth, J., Jacobs, K., Janku-Capova, L., Jeppson, T., Langridge, R., Mallyon, D., Marx, R., Massiot, C., Mathewson, L., Moore, J., Nishikawa, O., Pooley, B., Pyne, A., Savage, M. K., Schmitt, D., Taylor-Offord, S., Upton, P., Weaver, K. C., Wiersberg, T., and Zimmer, M.: Bedrock geology of DFDP-2B, central Alpine Fault, New Zealand, New Zeal. J. Geol. Geophys., 60, 497-518, https://doi.org/10.1080/00288306.2017.1375533, 2017. 
Turnbull, I. M., Mortimer, N., and Craw, D.: Textural zones in the Haast Schist - a reappraisal, New Zeal. J. Geol. Geophys., 44, 171-183, https://doi.org/10.1080/00288306.2001.9514933, 2001.

Upton, P., Song, B. R., and Koons, P. O.: Topographic control on shallow fault structure and strain partitioning near Whataroa, New Zealand demonstrates weak Alpine Fault, New Zeal. J. Geol. Geophys., 61, 1-8, https://doi.org/10.1080/00288306.2017.1397706, 2017.

Vermilye, J. M. and Scholz, C. H.: The process zone: A microstructural view of fault growth, J. Geophys. Res. Earth, 103, 1222312237, https://doi.org/10.1029/98JB00957, 1998.

Warr, L. N. and Cox, S.: Clay mineral transformations and weakening mechanisms along the Alpine Fault, New Zealand, in: Geological Society, London, Special Publications, vol. 186, edited by: Holdsworth, R. E., Strachan, R. A., Magloughlin, J. F., and Knipe, R. J., 85-101, The Geological Society, London, 2001.

Wellman, H.: Data for the Study of Recent and Late Pleistocene Faulting in the South, New Zeal. J. Sci. Technol., 34, 270-288, 1953.

Williams, J. N., Toy, V. G., Massiot, C., McNamara, D. D., and Wang, T.: Damaged beyond repair? Characterising the damage zone of a fault late in its interseismic cycle, the Alpine Fault, New Zealand, J. Struct. Geol., 90, 76-94, https://doi.org/10.1016/j.jsg.2016.07.006, 2016.

Williams, J. N., Toy, V. G., Smith, S. A. F., and Boulton, C.: Fracturing, fluid-rock interaction and mineralisation during the seismic cycle along the Alpine Fault, J. Struct. Geol., 103, 151-166, https://doi.org/10.1016/j.jsg.2017.09.011, 2017a.
Williams, J. N., Toy, V. G., Massiot, C., and McNamara, D.: X-ray Computed Tomography and borehole televiewer images of the Alpine Fault's hanging-wall, New Zealand: Deep Fault Drilling Project phase 1 (DFDP-1) and Amethyst Hydro Project (AHP), GFZ Data Serv., https://doi.org/10.5880/ICDP.5052.004, 2017b.

Wilson, J. E., Chester, J. S., and Chester, F. M.: Microfracture analysis of fault growth and wear processes, Punchbowl Fault, San Andreas system, California, J. Struct. Geol., 25, 1855-1873, https://doi.org/10.1016/S0191-8141(03)00036-1, 2003.

Wright, C. A.: Geology and paleoseismicity of the central Alpine Fault, New Zealand, 1998.

Yukutake, Y., Ito, H., Honda, R., Harada, M., Tanada, T., and Yoshida, A.: Fluid-induced swarm earthquake sequence revealed by precisely determined hypocenters and focal mechanisms in the 2009 activity at Hakone volcano, Japan, J. Geophys.-Res.Sol. Ea., 116, B04308, https://doi.org/10.1029/2010JB008036, 2011.

Zangerl, C., Loew, S., and Eberhardt, E.: Structure, geometry and formation of brittle discontinuities in anisotropic crystalline rocks of the central Gotthard massif, Switzerland, Eclogae Geol Helv., 99, 271-290, https://doi.org/10.1007/s00015-006-1190-0, 2006. 